\title{
Systematic evaluation of scenario assessments supporting sustainable integrated natural resources management: evidence from four case studies in Africa
}

\author{
$\underline{\text { Julia Reinhardt }}^{1}$, Stefan Liersch ${ }^{1}$, Mohamed Arbi Abdeladhim $^{2}$, Mori Diallo $^{3}$, Chris Dickens $^{4}$, Samuel Fournet $^{1}, \underline{\text { Fred Fokko }}$

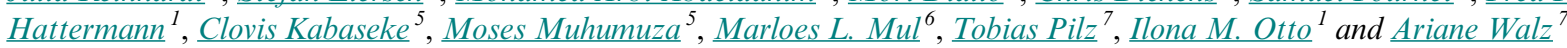

\begin{abstract}
Scenarios have become a key tool for supporting sustainability research on regional and global change. In this study we evaluate four regional scenario assessments: first, to explore a number of research challenges related to sustainability science and, second, to contribute to sustainability research in the specific case studies. The four case studies used commonly applied scenario approaches that are (i) a story and simulation approach with stakeholder participation in the Oum Zessar watershed, Tunisia, (ii) a participatory scenario exploration in the Rwenzori region, Uganda, (iii) a model-based prepolicy study in the Inner Niger Delta, Mali, and (iv) a model coupling-based scenario analysis in upper Thukela basin, South Africa. The scenario assessments are evaluated against a set of known challenges in sustainability science, with each challenge represented by two indicators, complemented by a survey carried out on the perception of the scenario assessments within the case study regions. The results show that all types of scenario assessments address many sustainability challenges, but that the more complex ones based on story and simulation and model coupling are the most comprehensive. The study highlights the need to investigate abrupt system changes as well as governmental and political factors as important sources of uncertainty. For an in-depth analysis of these issues, the use of qualitative approaches and an active engagement of local stakeholders are suggested. Studying ecological thresholds for the regional scale is recommended to support research on regional sustainability. The evaluation of the scenario processes and outcomes by local researchers indicates the most transparent scenario assessments as the most useful. Focused, straightforward, yet iterative scenario assessments can be very relevant by contributing information to selected sustainability problems.
\end{abstract}

Key Words: Africa; global and regional change; integrated assessments; participatory research; sustainability science

\section{INTRODUCTION}

Typically, human-natural systems are exposed to multiple, interlinked stresses (Peters et al. 2008). Local consumption, production patterns, and well-being, for instance, often depend not only on the region's economic and social conditions, but also on the capacities of ecosystems in other regions (Adger et al. 2009). Complex systems often react in a nonlinear way to stresses (Scheffer et al. 2001) because of, for example, crossing system thresholds such as environmental limits or feedback processes (e.g., Steffen et al. 2015). Assessments of future changes are subject to uncertainties that are associated with an incomplete understanding of complex systems, their unpredictable behavior, or human choices to be made in future, i.e., volition (e.g., Raskin et al. 2002, Ash 2010). There is still the question of how science can explore future changes in the human-natural system with its inherent complexity and uncertainty in order to effectively support society for sustainable management and equitable human development (e.g., Gibbons 1999, Kates at al. 2001, PahlWostl 2007).

Africa, with its great diversity of cultures and environments (UNEP 2006), has become the continent with the fastest growing economy (AfDB 2013). Increasing demands for natural resources have caused their widespread overexploitation and strong competition for these critical assets (UNEP 2006, Jalloh et al. 2012). Many African countries will need to make huge efforts to reach food and water security (Fader et al. 2013, Müller 2013, FAO 2015) because of high population growth (UN 2013), widespread low agricultural performance (Mueller et al. 2012), and potential climate change impacts (Niang et al. 2014). The magnitude of expected change and the low adaptive capacity of many communities in Africa pose a serious threat to local livelihoods. Strengthening capacities to maintain and improve well-being are therefore needed (Ludi et al. 2012).

In the face of the diversity, complexity, and pace of environmental and social change, the use of scenarios has become a key tool to analyze sustainability problems (Biggs et al. 2007). Scenario assessments analyze future changes using a variety of approaches. Quantitative scenario assessments provide detailed information that is often required for planning strategies and exploring current and future trade-offs (Hulme and Dessai 2008). An advantage of using numerical models is their ability to process big data sets, crucial in tasks such as climate change impact assessments (Shukla et al. 2009, Dessu and Melesse 2013, Aich et al. 2014). The advance in high-performance computing allows the study of impacts from a range of drivers on interrelated domains or subsystems using model coupling (Guan et al. 2015, Clarke et al. 2017). The evaluation of different sources of uncertainty in impact projections has been done by, for example, applying an ensemble of impact models (e.g., Kassie et al. 2015, Vetter et al. 2016). Apart from quantitative assessments, qualitative scenario

${ }^{1}$ Potsdam Institute for Climate Impact Research (PIK), Potsdam, Germany, ${ }^{2}$ Institut des Régions Arides, Médenine, Tunisia, ${ }^{3}$ Wetlands International Africa, Mali Office, Sévaré/Mopti, Mali, ${ }^{4}$ International Water Management Institute (IWMI), Southern Africa Office, Pretoria, South Africa, ${ }^{5}$ Mountains of the Moon University (MMU), Fort Portal, Uganda, ${ }^{6}$ International Water Management Institute (IWMI), Regional Office West Africa, Accra, Ghana, ${ }^{7}$ Institute of Earth and Environmental Science, University of Potsdam, Potsdam, Germany 
assessments are widely used. They are often participative, build on local knowledge of affected stakeholders, and are designed as social processes to foster the learning of participants (e.g., Fabricius et al. 2006, Pahl-Wostl 2008, Hulme and Dessai 2008, Malinga et al. 2013, AfDB and WWF 2015). In order to take advantage of the qualitative and quantitative approaches (e.g., Alcamo and Henrichs 2008), they are often combined into a storyand-simulation approach (e.g., Alcamo et al. 2005, Herrero et al. 2014).

How to design effective scenario assessments is discussed in many research fields (Kok et al. 2017, van Ruijven et al. 2014, van Vuuren et al. 2014). Comparing existing scenario assessments is helpful to guide potential scenario users and practitioners (e.g., van Notten et al. 2003, 2005, Busch 2006, van Vuuren et al. 2012, IPBES 2016) and as a way to determine research needs for enhancing their usage (van Ruijven et al. 2014). Swart et al. (2004) identified nine research challenges where sustainability science can benefit from the development of scenarios (see Text Box 1). Scenario analyses, according to their framework, are assumed to strongly support scenario users and practitioners in promoting sustainability. Whether meeting all these research challenges is indeed required to foster sustainability has not yet been investigated. A comparison of different scenario assessments can reveal their benefits and limitations in addressing these research challenges.

Box 1: Nine research challenges of sustainability science according to Swart et al. (2004).

1. Combining qualitative and quantitative analysis: Important aspects of sustainability problems, like values or culture, cannot be quantified like economic or biophysical processes.

2. Engaging stakeholders: Provides local knowledge, contributes to producing useful knowledge for the practice, and facilitates mutual learning.

3. Reflecting multiple stresses and functional complexity: Multiple, interacting driver impact on a region or system, at a variety of scales.

4. Integrating across themes and issues: Social, technological, economic, political, governmental-institutional, and environmental aspects of the human-natural system are interdependent.

5. Accounting for volition: Future human behavior and human decision can have strong but unpredictable impacts on the human-natural system.

6. Recognizing a wide range of outlooks: People have different values and preferences for the future.

7. Spanning spatial scales: Processes at different spatial scales (global, regional, and local) interact.

8. Accounting for temporal inertia and urgency: A long-term change requires decisions in the short term.

9. Reflecting uncertainty, incorporating surprise, critical thresholds, and abrupt change: In contrast to gradual changes, abrupt changes cannot be calibrated in models but have high impacts for the human-natural system. Thresholds are hard to measure.
The purpose of this study is to compare and evaluate four scenario assessments on urgent sustainability problems in four African case studies that were carried out within the framework of integrated natural resources management (INRM). The scenario assessments are evaluated against a set of indicators directly linked to the research challenges by Swart et al. (2004) and by means of a survey of local researchers on their perception of the usefulness of these scenario assessments to promote sustainability in their case study areas. In doing so, we aim to contribute to sustainability research by feeding into the ongoing debate on developing effective scenario assessments.

\section{THE FOUR CASE STUDIES}

\section{Description of the case study areas}

We refer to four regional case studies in Africa, all aiming to inform and improve INRM (see AFROMAISON project, http:// www.afromaison.net/ for more details). The four case studies are (1) the Oum Zessar watershed in southern Tunisia (OZW; Fig. 1A), (2) the Rwenzori region in western Uganda (RWR; Fig. 1B), (3) the Inner Niger Delta in Mali (IND; Fig. 1C), and (4) the upper Thukela / uThukela basin in South Africa (UTH; Fig. 1D; see Table A1.1 for details).

The case studies were selected for having strong local partners and established networks with stakeholders and authorities. All four are based in rural areas covering a diversity of ecoregions. Agricultural activities provide a major income source in all case studies, with growing demands leading to strong competition between different natural resource users, increasing degradation of natural resources, and increasing vulnerability of the local population.

The Oum Zessar watershed (OZW) experiences high water competition between different users because of water scarcity (Sghaier and Genin 2003). Groundwater, an important and reliable water resource for many sectors, is heavily exploited (Romagny et al. 2004). Pressures on water resources are increasing through population growth, urbanization, and land-use intensification (Nesheim et al. 2014). Water competition is likely to increase in the future, as climate change simulations project decreasing precipitation and increasing temperatures for northern Africa (Niang et al. 2014), further challenging water management (Omrani and Burger 2012).

The Rwenzori region (RWR) has one of the world's fastest growing populations; Uganda experiences annual growth rates of $3.2 \%$ (Baguwemu et al. 2013), and very high population densities locally (NEMA 2010). Competition for land and access to protected areas is increasing (Atukwatse et al. 2012), and meeting the growing food demand will be one of the challenges in this area (KRC 2012). Poor land-use planning and inappropriate land management practices such as bush burning, inappropriate forest cover clearing, or crop husbandry increase pressures on natural resources. (Kabaseke et al. 2012).

In the Inner Niger Delta (IND), natural resources such as bourgou pastures, fish, as well as rice strongly support local livelihoods (Zwarts and Diallo 2005) and are intensively exploited (van der Kamp et al. 2005). Their production depends mainly on the magnitude and duration of inundation in the inland delta (Zwarts and Kone 2005), which, because of low annual rainfalls locally, 
Fig. 1. The four case study localities in Africa, (A) Oum Zessar watershed (Tunisia), (B) Rwenzori region (Uganda), (C) Inner Niger Delta (Mali), (D) upper Thukela/uThukela (South Africa). WHS: World heritage site, MAB: Man and the biosphere program, NP: National Park. Elevation map: SRTM 30 arc (USGS/EROS Data center, FAO GeoNetwork, http://www.fao.org/geonetwork/srv/en/ main.home)

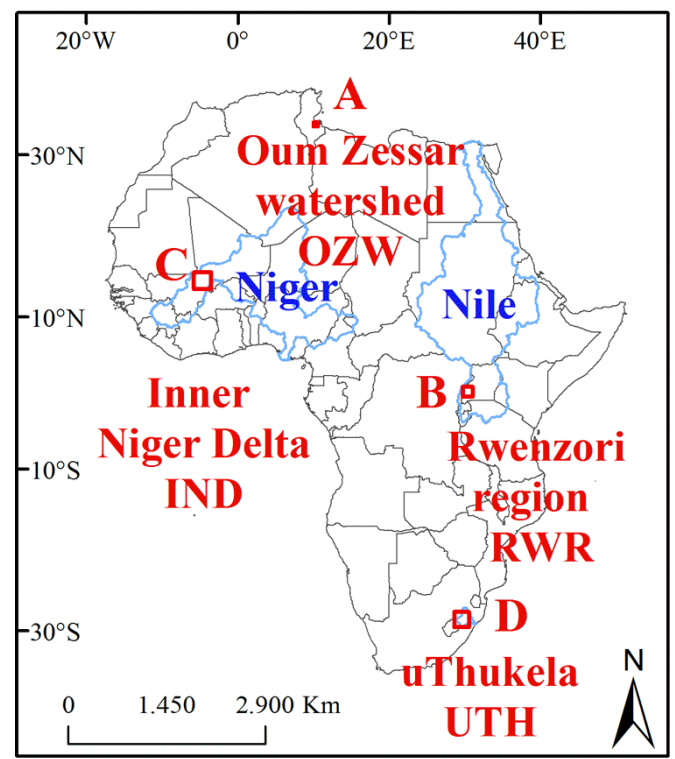

3 Case study areas

National parks

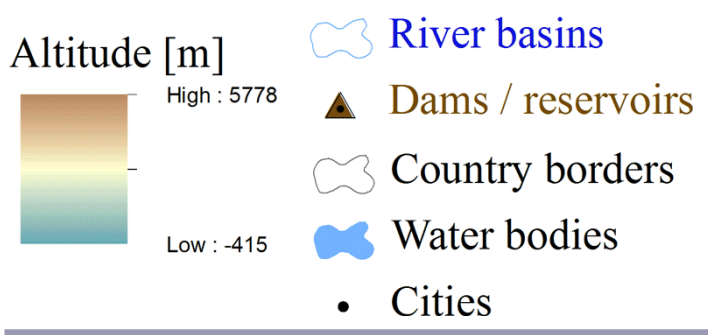

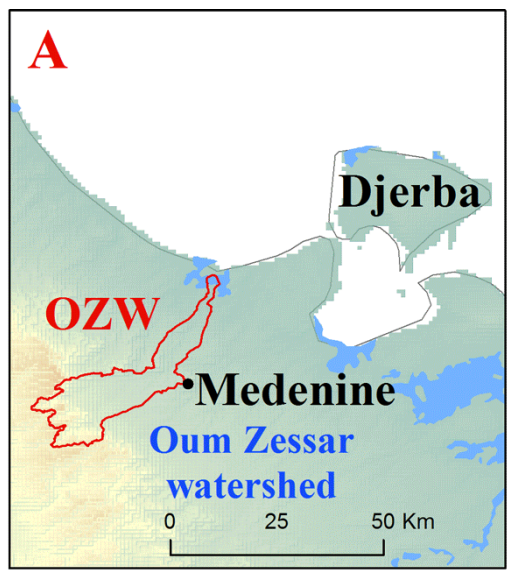
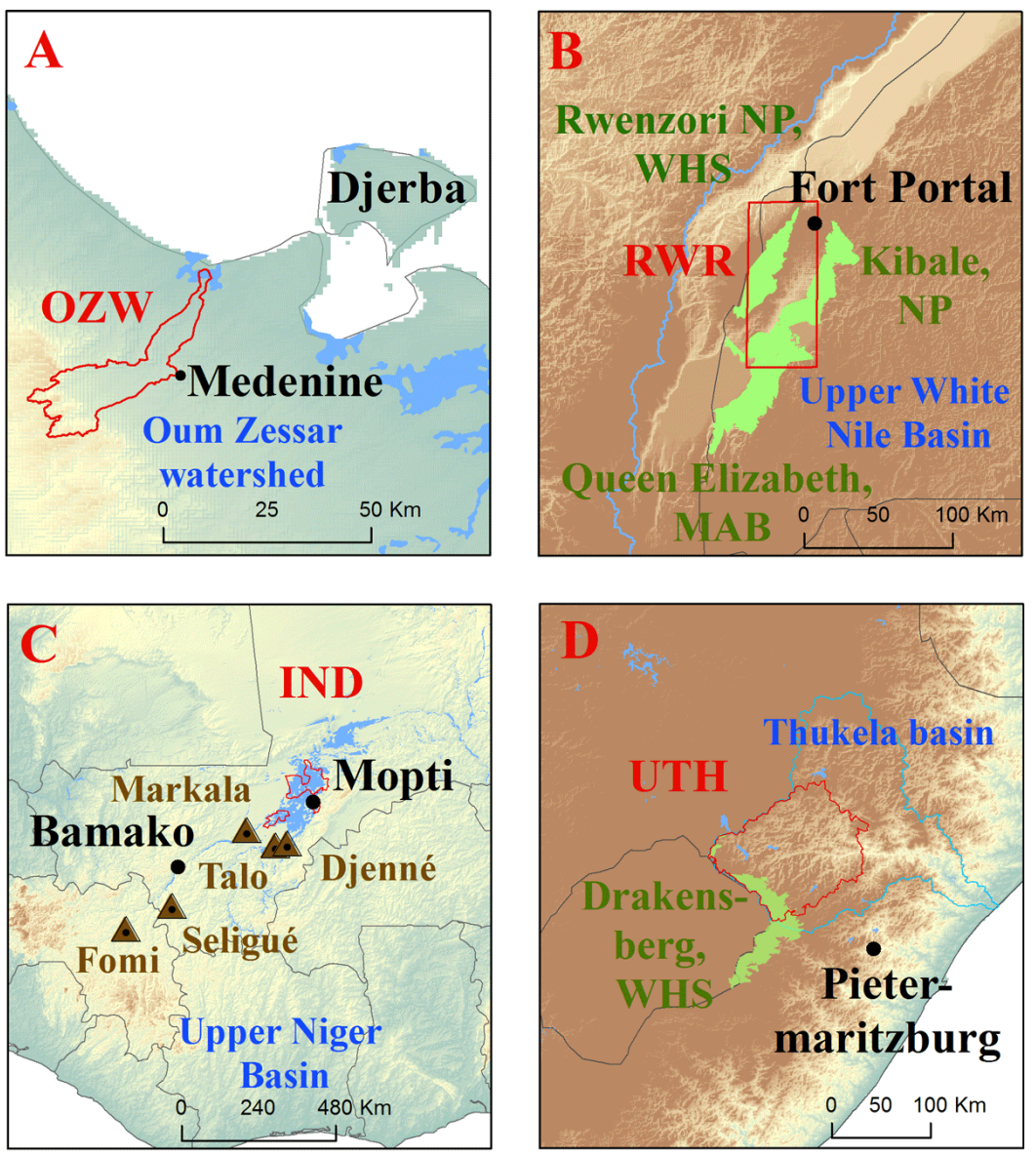

is a function of the inter- and intra-annual variability in river inflows. This is driven by external factors such as climate variability in the wetter upstream area and changes in the management of the upstream river basin. Because Mali and the other Niger River riparian countries experience pressures to meet the growing food and energy demand, several dams and reservoirs in the upstream catchment have been installed and more are planned, with supposedly huge impacts on the timing and amount of river discharge and thus food production in the delta (NBA 2007, Zwarts and Frerotte 2012, Liersch et al. 2013).

The uThukela basin (UTH) faces severe land degradation processes (Blignaut et al. 2010) because of high stocking rates, a symptom of inappropriate grazing management, and high population densities in rural areas (DWAF 2004, SANBI 2014). In Kwazulu Natal, $28.2 \%$ of the households are engaged in agriculture, the majority of them, i.e., in livestock farming (SSA 2011). Land degradation, together with climate variability (risk of droughts, flooding, hails), endangers food and water security in the region (Department of Environmental Affairs and Tourism 2006, Osbahr et al. 2010).

\section{Description of scenario assessment processes}

We used four stakeholder groups that have an interest in and/or manage natural resources within the project areas and that potentially affect and/or could be affected by project activities or the planning process. Participants are from policy communities (policy maker, donor), networks (farmer organizations, private sector), advocacy coalitions (e.g., NGOs), and epistemic communities (research institutions). The workshops of OZW, RWR, and IND comprised key stakeholders, namely regional experts with a particular field of expertise and influence that is relevant to the research question. These regional experts participated in three workshops in OZW and four workshops in RWR. Regional and national key stakeholders took part in a workshop in IND and a fourth workshop in OZW. A UTH workshop was attended by regional experts and interested nonexperts (civic citizens). The different stakeholder groups were engaged or at least informed during the scenario assessments (see Table A1.2 to Table A1.5 for workshop details).

Table 1 summarizes the main outcomes of each scenario assessment. As a first step, each case study defined a focal issue 
Table 1. Summary of the outcomes of the four scenario assessments.

\begin{tabular}{|c|c|c|c|c|}
\hline Case study & Oum Zessar watershed (OZW) & Rwenzori region (RWR) & Inner Niger Delta (IND) & Upper Thukela (UTH) \\
\hline Focal issue & $\begin{array}{l}\text { How to preserve and manage the water } \\
\text { resources and the socio-agro-ecological } \\
\text { system for sustainable development? }\end{array}$ & $\begin{array}{l}\text { Sustainable natural resource } \\
\text { management for } \\
\text { socioeconomic development }\end{array}$ & $\begin{array}{l}\text { What are the impacts of } \\
\text { upstream dam and irrigation } \\
\text { management and climate } \\
\text { change on food security and } \\
\text { ecosystem integrity in the } \\
\text { Inner Niger Delta? }\end{array}$ & $\begin{array}{l}\text { What are the implications of } \\
\text { current management } \\
\text { frameworks on ecosystem } \\
\text { services (particularly water } \\
\text { regulation) in the uThukela } \\
\text { District, particularly in the } \\
\text { face of growing human } \\
\text { demand and climate change? }\end{array}$ \\
\hline $\begin{array}{l}\text { Number and types } \\
\text { of scenarios }\end{array}$ & $\begin{array}{l}\text { Four multiscale narratives (national } \\
\text { and regional): } \\
\text { 1) Liberalization and market } \\
\text { orientation } \\
\text { 2) Sustainable development and } \\
\text { technological improvements } \\
\text { 3) Conflict-torn market orientation } \\
\text { 4) Corporate commitment for equity } \\
\text { and sustainability }\end{array}$ & $\begin{array}{l}\text { Four narratives: } \\
\text { 1) Autocratic dangerous } \\
\text { 2) Ideal } \\
\text { 3) Current Ugandan } \\
\text { 4) Worst case }\end{array}$ & $\begin{array}{l}\text { Seven scenarios of land } \\
\text { management options, each } \\
\text { combined with climate } \\
\text { change scenarios }\end{array}$ & $\begin{array}{l}\text { SWIM model \#: six scenarios } \\
\text { along a gradient of grazing } \\
\text { intensity, three reservoir } \\
\text { management options; each } \\
\text { combined with climate change } \\
\text { scenarios }{ }^{\dagger} \\
\text { Coupled models: population } \\
\text { growth, livestock growth }\end{array}$ \\
\hline
\end{tabular}

\begin{tabular}{|c|c|c|}
\hline & scenarios & \\
\hline $\begin{array}{l}\text { Indicator for } \\
\text { impact assessment }\end{array}$ & $\begin{array}{l}\text { Qualitative: water provisioning, } \\
\text { different income sources, education, } \\
\text { social networks, and social satisfaction } \\
\text { Quantitative: groundwater resources }\end{array}$ & $\begin{array}{l}\text { Qualitative: poverty / income, } \\
\text { access to clean water, food } \\
\text { security, or illiteracy }\end{array}$ \\
\hline Outputs & $\begin{array}{l}\text { Qualitative: } \\
\text { driver systematization (STEEP }{ }^{\ddagger} \text { ) } \\
\text { system definition in concept map } \\
\text { trend assumption on drivers, livelihood } \\
\text { and management, scenario narratives } \\
\text { (after Schwartz } 1996^{\S} \text { ) } \\
\text { SWOT analysis } \\
\text { Quantitative: projections on } \\
\text { groundwater resources under climate } \\
\text { change and socioeconomic }^{\text {development scenarios (WEAP }} \\
\text { model }{ }^{\uparrow} \text { ) }\end{array}$ & $\begin{array}{l}\text { Qualitative: } \\
\text { driver systematization } \\
\left(\mathrm{STEEP}^{\dagger}\right) \\
\text { system definition in concept } \\
\text { map } \\
\text { trend assumption on drivers, } \\
\text { livelihood, land degradation, } \\
\text { narratives (after Schwartz } \\
1996^{\S} \text { ) }\end{array}$ \\
\hline
\end{tabular}

Quantitative: maximum inundated area, river discharge

Quantitative: estimations of impacts of different upstream measures under climate change uncertainty (SWIM model \#)
Quantitative: grassland biomass production, runoff, land-use change

Qualitative: framework on model coupling Quantitative: estimations of impact of grazing, reservoir management scenarios under climate change uncertainty (SWIM \# and SITE model ${ }^{\dagger \dagger}$ )

More details on climate data can be found in Text Box A1.1.

\$ STEEP analysis: Situation analysis where Socio-cultural, Technological, Economic, Environmental, and Political-legal factors are described.

Basically Schwartz (1996) was followed (a) identifying the most important drivers, (b) ranking them by their importance and unpredictability, (c) defining the scenario logics using two axes, (d) fleshing out narratives and trends, (e) discussing implications, and (f) defining leading indicators and signposts I SWOT analysis, where internal Strengths and Weaknesses as well as extePrintable Version...rnal Opportunities and Threats are analyzed, developed by the Harvard Business School in the 1960s (see Andrews 1980, as cited in Kotler et al. 2010)

"WEAP model (Water Evaluation And Planning; http://www.weap21.org/) is a water allocation model (Yates et al. 2005). It was first used by Raskin et al. (1992) in the Aral Sea region and has been applied widely for evaluating and assessing water management strategies taking an integrated perspective (see http://www.weap21.org/index.asp?action=216).

\# SWIM model (Soil and Water Integrated Model) is a semidistributed continuous-time eco-hydrological model (Krysanova et al. 1998, 2005). It has been widely applied for simulating river-basin scale hydrological processes, vegetation growth, erosion, and nutrient dynamics (Krysanova et al. 2015), reservoir management, and irrigation water uptake (Koch et al. 2013) as well as inundation processes (Liersch et al. 2013).

${ }^{\dagger}$ SITE model (SImulation of Terrestrial Environments) is a generic framework for integrated land-use modeling. It produces spatially explicit land-use dynamics through a specified set of rules (Schweitzer et al. 2011). The SITE model has been applied in various contexts (Priess et al. 2011, Das et al. 2012).

or research scope on which to develop scenarios. The OZW and RWR focused on sustainable development by improving INRM of specific natural resources under pressure. Research in the IND and UTH assessed the impacts of climate change and various land and water management options on natural resource availability. Each case study selected scenario drivers, either as a first step in scenario development by involving stakeholders, developing concept maps, and using the Social-TechnicalEconomic-Environmental-Political (STEEP) framework (OZW, RWR), or from earlier research activities (IND, UTH; e.g., Liersch et al. 2013).
The type of scenario approach applied in the case studies was mainly determined by the role and objectives of the scenario assessment in the INRM decision-making and planning process, key drivers, available resources, and data availability. The four scenario approaches encompass a story and simulation approach (OZW), a participatory scenario exploration (RWR), a modelbased prepolicy study (IND), and a scenario exploration based on model coupling (UTH).

The participatory qualitative scenarios in the OZW and RWR were developed using the scenario axes technique inspired by Schwartz (1996). Concept maps were elaborated to define the 
main factors, drivers, and processes. In the OZW, participatory scenarios were evaluated qualitatively according to the StrengthsWeaknesses-Opportunities-Threats (SWOT) framework (see Andrews 1980, as cited in Kotler et al. 2010) and simulated using the Water Evaluation and Planning (WEAP) model (Yates et al. 2005). In the IND, the eco-hydrological model Soil \& Water Integrated Model (SWIM; Krysanova et al. 1998, 2005) was used to simulate the scenarios, similar to a previous study by Liersch et al. (2013). In the UTH, the SWIM model and the land-use model SImulation of Terrestrial Environments (SITE; Schweitzer et al. 2011) were coupled in order to simulate the scenarios (see van der Kwast et al. 2013).

The aim of the participatory scenario assessments (OZW, RWR) was to assess qualitative impacts related to a number of indicators. In quantitative assessments, impacts were projected on either one (OZW), two (IND), or three indicators (UTH). To account for climate change impacts, the scenario periods ranged from today until 2050. More information on the climate change scenarios can be found in Text Box A1.1.

\section{METHODS}

We descriptively evaluate the performance of the four case studies for each of the nine research challenges from Swart et al. (2004) and their effectiveness in potentially enhancing sustainability. The evaluation on the research challenges was done by the researcher team involved in all scenario assessments. The scientific effects of the scenario assessments such as a contribution to new scientific insights and methods (Walter et al. 2007) were collated from a survey of local researchers.

The research challenges were addressed by systematically evaluating scenario products (such as driver definition, narratives) and scenario process features (such as degree of stakeholder engagement, type of tools used) on the basis of an indicator set. Drawing on a literature review, the researcher team designed an indicator set that characterized the processes and outcomes of scenario assessments according to a range of aspects (van Notten et al. 2003, Swart et al. 2004, Biggs et al. 2007, Niemeijer and de Groot 2008, Albert 2013). Two indicators were specified for each research challenge (see Table 2). The specification took into account the measurability, relevance, and intelligibility of the indicator set for scenario assessments as well as the data availability across all case studies (see, e.g., Walz 2000, Niemeijer and de Groot 2008). Using two indicators for each research challenge increases the robustness of the measure and highlights different levels and diverse aspects of implementation.

In five of the nine research challenges $(1,2,6-8)$, the two indicators within each research challenge reflect different levels of implementation. The first of the two indicators always describes the lowest possible level of implementation, for example, in research challenge 7 the integration over two spatial scales. Thus, it asks whether a research challenge was addressed or not. The second indicator is always used to describe a more complex level of implementation, for example, two-directional scale interactions in research challenge 7 . The indicators of research challenges 3 to 5 and 9 represent two different aspects or ways of implementation in scenario assessments. For example, the first indicator of research challenge 4 characterizes the integration across themes and issues regarding drivers and the second one regarding impact analysis.
The case studies were compared by the researcher team using the score of indicators per research challenge. A minimum score of zero (no indicator of a research challenge was addressed by a case study) and a maximum of two (both indicators were addressed) was possible for each research challenge.

For the survey, local researchers were chosen because they often act as knowledge brokers in their regions. They were selected because of their knowledge and personal interest in the region, and also their degree of formal education. They are important influential persons in their regional networks who provide policy advice, initiating and coordinating (participatory) projects, and maintain contact with other stakeholders, besides advancing scientific knowledge within the region (see Reyers et al. 2015). They were the only stakeholders who had an overview over the whole research process.

The self-administered surveys were carried out approximately one year after finalizing the scenario process (more details on the evaluation in Table A2.1). Groups of two to four researchers per case study were surveyed once and provided an overall evaluation on behalf of their team.

Building on existing literature, the survey consisted of 33 questions, spanning credibility, salience, legitimacy, and capacity building as criteria or principles to bridge the divide of science and nonscience (Cash et al. 2002, Hegger et al. 2012, Chaudhury et al. 2013, Belcher et al. 2016). Credibility describes the technical quality and adequacy of information, salience its relevance for decision making, and legitimacy whether the whole process was fair and respectful of stakeholders (Clark et al. 2016). Capacity building is required to be able to adapt to changes (Kates et al. 2001). The questions could be scored on an ordinal scale between 1 (I absolutely do not agree) and 5 (I absolutely agree; Table A2.2). Each research challenge was operationalized with at least one question in the survey in order to evaluate the benefit from the local researcher's side (see Table A3.1 for details). The remaining questions of the survey were used as additional information to evaluate the overall effectiveness of the four scenario assessments.

The comparison and evaluation of the four scenario assessments was done mostly qualitatively using radar charts and bar plots for visualising results. Figure 2 shows the different research steps. Text Box A3.1 provides details on the contribution of the research team members to this evaluation.

\section{RESULTS}

Summary of the scenario building process in each case study The scenario assessments were used to analyze the following scenario drivers: in OZW the transition period and economic reorientation after the Tunisian revolution in 2010/2011, in RWR the level of environmental awareness of the local population and governmental effectiveness in implementing laws and policies, in IND a new ensemble of climate change scenarios and upstream management options, and in UTH, climate change as well as reservoir and grazing management (Fig. 3).

Scenario drivers were analyzed regarding possible changes in future water availability and regional development prospects (OZW and IND) as well as food provisioning (IND). The RWR and UTH studied land degradation with impacts on food production (RWR) and food and water provisioning (UTH). 
Table 2. Main findings regarding the implementation of the nine research challenges in the four case studies. CC $=$ climate change, NRM = Natural Resources Management, OZW = Oum Zessar watershed, RWR $=$ Rwenzori region, IND = Inner Niger Delta, UTH = upper Thukela / uThukela basin.

\begin{tabular}{|c|c|c|c|}
\hline OZW & RWR & IND & UTH \\
\hline
\end{tabular}

1. Combining qualitative and quantitative methods

1.1. Scenario development used quantitative and qualitative tools

Participatory qualitative scenario exploration, use of water allocation model

1.2. Scenario development produced quantitative and qualitative scenario outcomes Narratives and simulation analysis

2. Engaging stakeholders

2.1. Stakeholders were informed during the scenario process Four workshops
Two workshops

2. Stakeholders were actively involved to produce scenarios in a science-practice exchange process In three out of four workshops In both workshops

3. Reflecting functional complexity and multiple stresses

3.1. The scenarios were driven by at least two drivers
Tunisian revolution, economic
Environmental awareness,
NRM, CC reorientation governmental effectiveness

Model coupling framework,

(Coupled) Eco-hydrological model and land-use model $\mathrm{CC}$

3.2. The drivers were described by multidimensional assumptions Participatory: complex textual Complex textual assumptions for assumptions for drivers and their drivers and their interaction

A range of technical assumptions was interaction combined into six strategies assessed Simulation: trends on water under $\mathrm{CC}$ conditions consumption and management per sector under CC conditions

4. Integrating across themes and issues

4.1. Drivers represented at least two different sectors/domains $\begin{array}{ll}\begin{array}{l}\text { Economic, institutional, political, Institutional, political, environmental, Technological and environmental } \\ \text { social, and environmental }\end{array} & \text { and social }\end{array}$ social, and environmental

4.2. Impact analysis for at least two different sectors Regional NRM, water provisioning, Land degradation, food provisioning, Water and food provisioning and livelihood

5. Accounting for volition

5.1. Analysis of a type of human behavior or human decision as an external driver impacting the regional scale Stability and priorities of governance Stability and priorities of governance Upstream management options, and political frameworks, climate and political frameworks, effectiveness climate change change in implementing laws and policies

5.2. Analysis of a type of human behavior or human decision as an internal driver or factor Proactive vs. reactive NRM, role of Environmental awareness of local social networks population, proactive vs. reactive NRM

Social and environmental

Biomass and water provisioning

Climate change

Rule-based decision making to simulate land-use change

Six scenarios each combined with climate change scenarios

6. Recognizing a wide range of outlooks

6.1. Scenarios showed different outlooks on regional future development Four narratives, three of them $\quad$ Four narratives $\quad$ Seven scenarios (one is BAU) quantified combined with CC scenarios

6.2. Scenarios reflect different regional scale preferences and values regarding future development of the regions Different priorities for main economic Different cultural values, traditions, sectors, types of lifestyles, protection protection states of RWR national states in OZW park

7. Spanning over spatial scales

7.1. Scenarios spanned at least two spatial scales External drivers impact on regional External and regional drivers impact processes on regional processes

External drivers impact on regional processes

7.2. Scenarios included bidirectional scale interactions (multiscale scenarios with feedbacks) Interlinked national and regional narratives

8. Accounting for temporal inertia and urgency

8.1. Analysis of drivers and processes regarding their (different) temporal scales Short-term NRM options and different development pathways under $\mathrm{CC}$ conditions

8.2. Use of temporal scales of drivers and processes to develop dynamic scenario trajectories Narratives developed using 10-year time steps and feedbacks between scales and sectors

9. Reflecting uncertainty
Short-term upstream NRM strategies under CC
External and regional drivers impact on regional and local processes
NRM and land-use change under CC conditions

Simulation of yearly changing land use due to CC and static NRM assumptions 
9.1 Scenario development included surprising events or abrupt changes Tunisian Revolution Natural catastrophes

9.2. Scenario development included a threshold Participatory:

social tolerance on land degradation, maximum sustainable water

abstractions to introduce management changes
Extreme scenario on size of irrigation area (due to land grabbing), new dams / reservoirs in upstream area

Minimum sustainable biomass for grazing
Fig. 2. Research steps followed during this study to systematically evaluate the case studies based on different sources of materials. The left side of the circle describes the steps for analyzing scenario products and scenario process features and the right side visualizes the steps for collecting data through surveys.

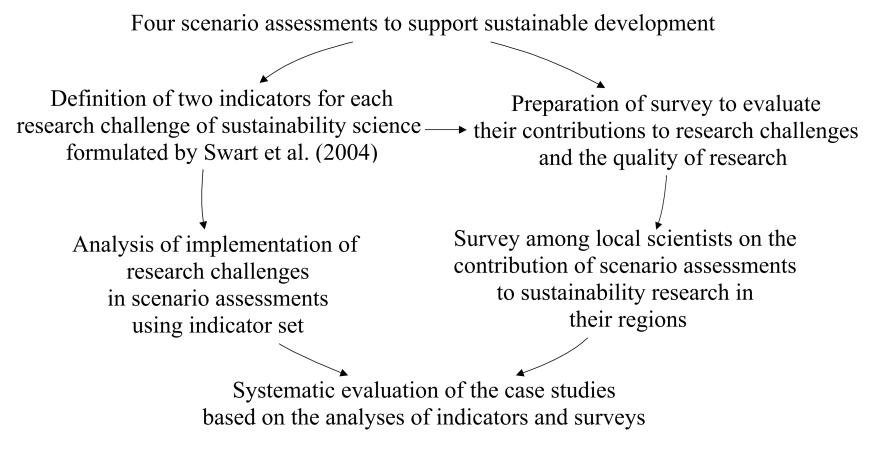

The main characteristics of all scenario assessments are presented in Figure 3. More details regarding scenario contents are provided below when we outline the contribution of each case study to the indicators of the sustainability challenges.

\section{Contribution of each case study to the sustainability research challenges}

The OZW and UTH addressed all nine, IND eight, and RWR seven research challenges (Table 2, Fig. 4). Only OZW addressed both indicators in all nine research challenges, whereas RWR addressed both in five cases, IND in two, and UTH in three. Summing up over all research challenges, OZW had a full score of indicators, IND and the RWR the lowest score, and the UTH ranked in between.

Of all research challenges, research challenge 4 (integrating themes) was the most addressed with both indicators being relevant to all case studies and research challenges 1 and 7-9 (combining qualitative and quantitative analysis, spatial scales, temporal scales, uncertainty) the least. Research challenges 1 and 8 were not addressed by all case studies.

\section{Combining qualitative and quantitative analysis}

The OZW and UTH applied qualitative and quantitative tools, RWR followed a qualitative approach, and IND was a quantitative model-based analysis. The RWR and OZW produced narratives and OZW subsequently simulated three out of four scenarios using a water allocation model. The UTH first analyzed the main regional processes to develop a qualitative framework for model coupling (van der Kwast et al. 2013), which was then implemented (Pilz 2013, Yalew et al. 2014).

\section{Engaging stakeholders}

All case studies informed stakeholders at the beginning of the project about the research plans and consulted them to define the focal issue. In OZW and RWR, stakeholders were actively involved in developing qualitative scenarios, whereas assessments in IND and UTH were science-driven. All case studies transferred scenario outcomes to stakeholders except UTH.

\section{Reflecting multiple stresses and functional complexity}

All case studies analyzed multiple stresses (two to three drivers) but with a varying degree of complexity. In the participatory assessments of OZW and RWR, participants selected the two most important and uncertain drivers for the focal issue and described them using a set of characteristics. For instance, the transition period after the Tunisian revolution (OZW), either short or long, was characterized by, for example, the length of time without a constitution, the stability of the political situation, corruption levels, a preference for short- vs long-term measures, or (in)effective governance. Participants then developed ways in which the two drivers might interact (example in Box A2.1). In the model-based exercises (IND, UTH, OZW), drivers encompassed a range of numbers on NRM (Natural Resources Management) and climate change projections. In IND, upstream management assumptions included the settings of built and planned reservoirs, current and future extensions of the seven main irrigation areas, and different assumptions pertaining to water use efficiency. In OZW it encompassed a range of assumed future land and water uses. In contrast to the other three, UTH defined driver assumptions straightforwardly, whereby grazing management (variation of levels of grazing intensity and different grazing lengths) and reservoir management (variation of levels of water abstraction) were tested under climate change conditions.

Integrating across themes and issues

Scenarios in OZW, RWR (qualitative parts), and UTH integrated different themes more than in IND. In these three case studies the developed conceptual models (concept maps, model coupling framework) served as the discussion and description of the key factors and processes over a range of domains (example in Figure A2.1). The IND, however, was strongly focused on hydrology although different technical management details were simulated using an integrated model. Food provisioning was estimated through functional relationships to the projected maximum inundated area and river discharges (see Zwarts et al. 2005, Liersch et al. 2013). The simulation in OZW required a substantial reduction of complexity. It was based on a quantifiable subset of water allocation and management trends, which were logically linked to the development trajectories of the narratives. 
Fig. 3. Scenario contents of each case study. Specified interactions between drivers are marked by arrows. Horizontal boxes (OZW, IND): only external scale scenario drivers used; vertical boxes (RWR, UTH): external and internal scale scenario drivers used. Green colors signify the natural system, black the human system, orange surprises, and orange italic colors thresholds. Grey boxes show where volition was addressed. Underlined concepts: quantitative parts of scenarios, else qualitative. $\mathrm{CC}=$ climate change, $\mathrm{NRM}=$ Natural Resources Management, OZW = Oum Zessar watershed, RWR = Rwenzori region, IND = Inner Niger Delta, UTH = upper Thukela / uThukela basin.

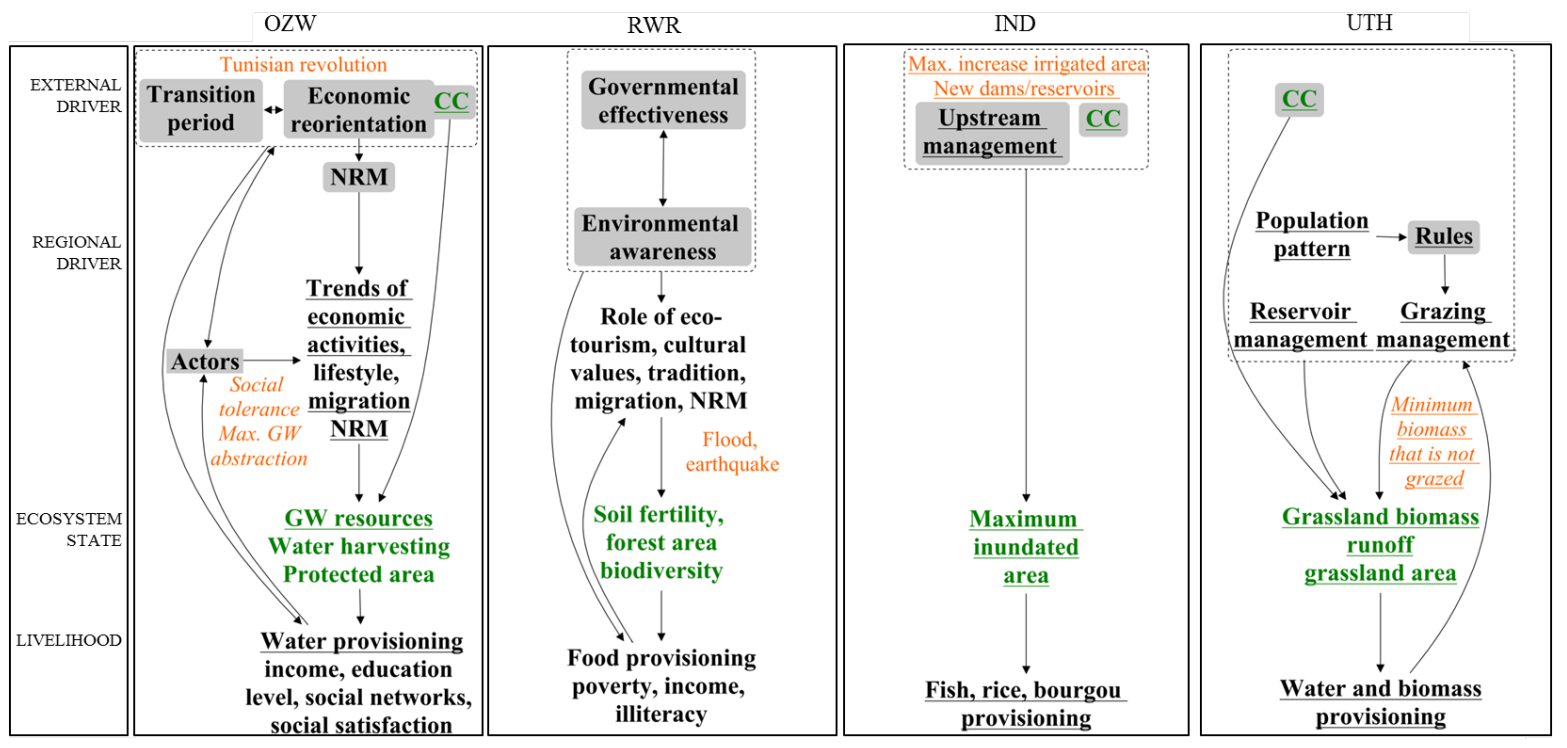

Livelihood was addressed through the development progresses of different water-dependent sectors. The UTH studied social (population distribution and growth, rule-based land use) and environmental (NRM and climate change) impacts on changes in land use, annual biomass production, and runoff (Yalew et al. 2014).

\section{Accounting for volition}

All case studies assessed the potential implications of a type of human decision that is outside of the stakeholder's sphere of influence: impacts related to the priorities and efficiency of national-scale governance and policy making, and/or climate change. Three case studies also analyzed volition as an internal driver or factor that was controllable by local people. In OZW, for instance, the level of social commitment and cooperation (number of people involved in NGOs, the quality of social networks) introduced differences within the scenarios. In UTH, rules for a decision-based land-use change were used, conceptualized in Figure 3 as "Rules." Rules were introduced for spatially explicit grazing suitability, which declines, for example, with distance from a grid cell of a water class and therefore also relates to socioeconomic factors such as water infrastructure and population growth.

\section{Recognizing a wide range of outlooks, including values and} preferences

Scenarios in all case studies spanned various regional-scale futures. Those for OZW and RWR also reflected different values and preferences of the local people. In OZW this is depicted in the development of, for example, agriculture (irrigated vs traditional techniques) or lifestyle (more globalized vs. more traditional). In RWR, cultural values and traditions for implementing adaptation strategies were discussed. Scenarios for IND, in contrast, reflected a system that is completely dependent on the management of the upstream catchment. However, they can support (national) decision makers' choice of one management strategy over another. The assessment for UTH was a sensitivity analysis designed to study system behavior.

Spanning spatial scales

All scenarios covered a variety of scales with mostly external drivers impacting the regional-scale ecosystem and livelihood. The UTH assessed impacts also at the local scale by producing site-specific information.

Spatial scale interactions were developed either unidirectionally (RWR, IND, UTH) or in both directions (OZW). Unidirectionally means that drivers impact regional processes, but not the other way around. In contrast, bidirectional interactions in OZW introduced feedback (represented in Fig. 3 through NRM at both scales). An example is the first Tunisian scenario "Liberalization and market orientation," focusing on rapid economic growth. The scenario team evaluated a rapid economic growth until 2050 as implausible mainly because of four reasons. First, Tunisia's economy would be increasingly vulnerable to external shocks because of its strong exportorientation. Second, income disparity was assumed to increase, leading to higher poverty rates and social discontent. Third, Tunisia's limited water resources constrain exploitable natural resources. Fourth, because of the relatively high environmental awareness of the Tunisian population, high environmental degradation would not be tolerated. Based on these arguments, a paradigm change along the scenario time frame was assumed. 
Fig. 4. Contributions of case studies to the indicators specified for each research challenge. The inner/ middle/outer ring symbolizes that no/one/two indicators were addressed. Numbers refer to the research challenges: (1) combining qualitative and quantitative analysis, (2) engaging stakeholders, (3) reflecting functional complexity and multiple stresses, (4) integrating across themes and issues, (5) accounting for volition, (6) recognizing a wide range of outlooks, (7) spanning spatial scales, (8) accounting for temporal inertia and urgency, and (9) reflecting uncertainties, here related to integrating surprises and thresholds. OZW = Oum Zessar watershed, RWR = Rwenzori region, IND = Inner Niger Delta, UTH = upper Thukela / uThukela basin.

\section{OZW}

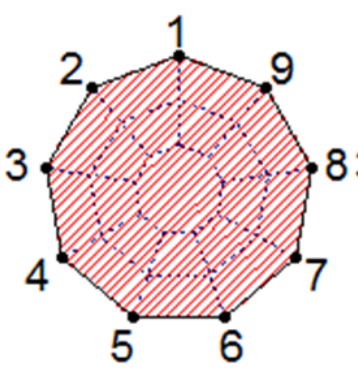

RWR

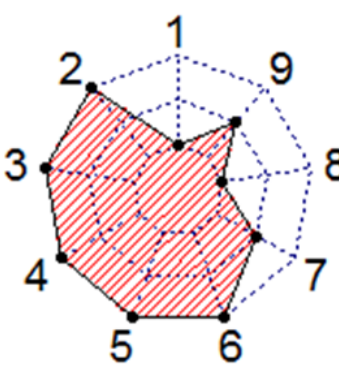

IND

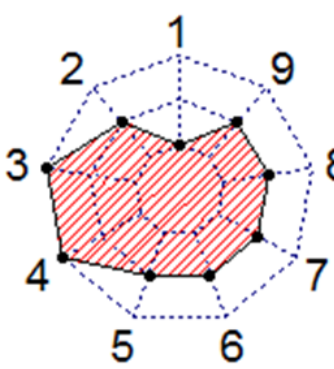

UTH

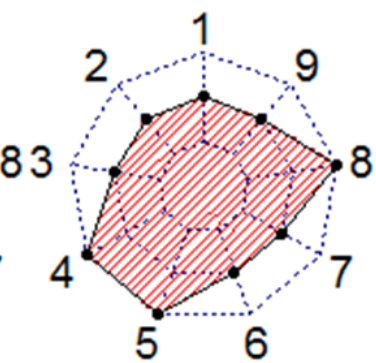

\section{Accounting for temporal inertia and urgency}

To analyze causes and effects that potentially occur on different time scales was the goal in all case studies except RWR. However, only OZW and to some extent UTH considered feedbacks / an adaption of factors that rather affect the short term (management options to be pursued now) to those causing changes over long periods (like climate change). In OZW, assumptions on scale and sector interactions and available water resources caused changes (dynamics) in regional NRM within the scenario periods. In UTH, land use was a function of climate change and of a threshold of sustainable grassland management. In contrast, NRM in UTH and upstream NRM in IND remained constant during the simulation runs.

It was challenging to find a suitable solution to integrate climate change issues in the participatory exercises (RWR, OZW). Finally, knowledge of climate change projections was presented and indirectly considered by participants as additional information on future changes in general.

\section{Reflecting uncertainty by incorporating surprises, unexpected trajectories, and critical thresholds}

Surprises, abrupt changes, or unexpected trajectories were a focus in OZW, RWR and IND. In OZW, the abrupt change after the Tunisian revolution was assessed along four transformation pathways. The RWR scenario team analyzed the possible impacts of natural catastrophes (earthquakes and floods) by adapting existing scenarios. In IND, an extreme scenario was simulated to show potential impacts if all land that was allocated to large-scale farming investors in the past 10 years were to be developed for irrigation farming (see Hertzog et al. 2012). Moreover, the implementation of new reservoirs implies abrupt changes with an immediate impact on the hydrological regime.

Only UTH included an explicitly defined ecological threshold on sustainable grassland management, which is a minimum biomass that is not grazed (Yalew et al. 2014). Stakeholders in OZW assumed a threshold of sustainable water abstraction to develop sustainable future pathways. NRM was changed when they expected longer term unsustainable water abstraction and intolerable land degradation. Preliminary simulation results indicated a fast depletion of groundwater resources in the first scenario because of unrealistic increasing water demands, especially for irrigation. Initial test runs in UTH using the coupled SITE and SWIM models indicated that $35 \%$ of the grassland areas do not produce sufficient biomass for sustainable grazing, i.e., they do not surpass the recommended threshold. Grazing pressures may thus lead to soil and grassland degradation (Yalew et al. 2014).

\section{Evaluation of the scenario process and outcomes by local researchers}

In general, the surveyed researchers of all case studies evaluated the scenario process and its outcomes as being beneficial for sustainability research within the framework of INRM (Fig. 5, Table A2.2). The evaluations of RWR and IND were the most positive, OZW ranks after them, and UTH last. The results of the surveys suggest that out of the four criteria related to the potential of our research to bridge science and nonscience, the relevance of the scenario process and outcomes is perceived as most different between case studies.

Comparing the respective responses per research challenge with the score of indicators shows no evidence that a higher score for the indicators is related to a better evaluation of the process and outcomes for sustainability research in the case studies (Fig. 6). The surveys show a similar high agreement across all case studies on the contribution to research challenges 1,3 , and 4 . For the other research challenges, the responses are more diverse. In the following, the results of the surveys and the indicator scores are compared for each research challenge.

Results for research challenge 1 show that the quality of scenarios and tools are evaluated high despite the use of different scenario approaches by the different case studies. A reason for the equally positive results for research challenges 3 and 4, the integration of 
Fig. 5. Evaluation of the local researchers regarding the credibility of scenarios, the relevance of the scenario process and outcomes, the salience of the scenario process, and the contribution of the scenario process and outcomes to capacity building. Dark blue represents the maximum score for each group and red the lowest score. More details on the survey are given in Table A2.1 and Table A2.2; the number of questions (n) in each criterion is indicated below the subfigures. OZW = the Oum Zessar watershed, RWR $=$ Rwenzori region, IND = Inner Niger Delta, UTH = upper Thukela / uThukela basin.

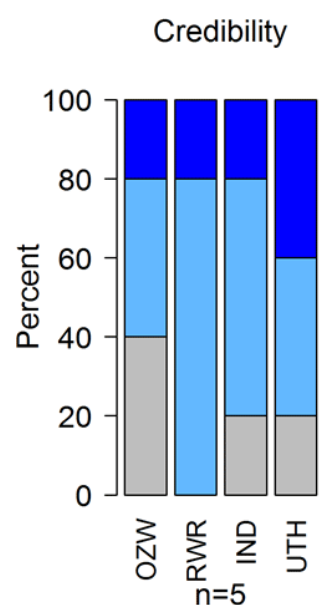

Salience

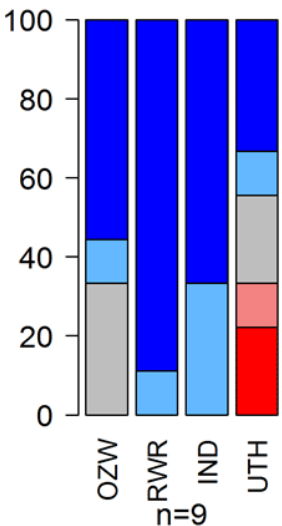

Legitimacy

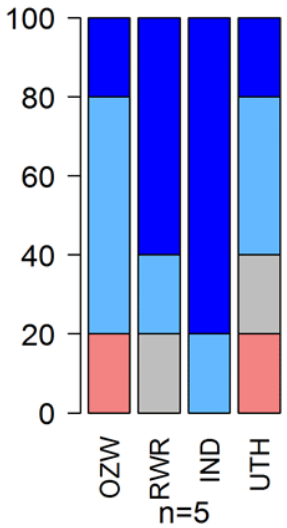

Capacity building

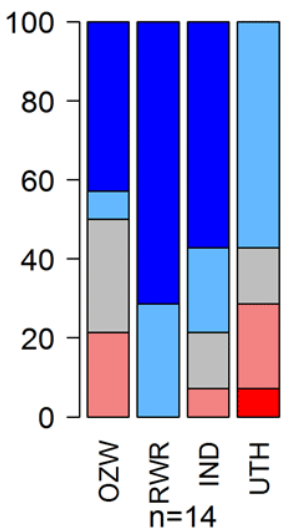

I absolutely do not agree $\square$ I partially agree $\square$ I agree I do not agree

multiple stresses and of different themes and issues, is that survey responses for these research challenges partly overlapped.

Stakeholder work (research challenge 2) is evaluated as fair and effective in RWR and IND, whereas scientists from OZW and UTH perceive a lack of openness to participation in the process. In UTH, scenarios are found to lack relevance, because the time schedules for the scenario assessment and the regional planning document did not coincide. For this reason, scenario outcomes could be shared with the scientific community but not with the broader public.

Researchers of RWR and IND perceive the most value for understanding the implications of volition (research challenge 5). Although the OZW scenarios addressed many different types of volition, these resulted in only a low perceived gain in capacity.

Regarding research challenge 6 , recognizing a wide range of outlooks, the UTH records the lowest value of all case studies on people's values and preferences for future development, an issue that was not addressed in their scenarios. Researchers of the OZW also evaluate the assessment as not very beneficial in this point but, unlike for UTH, it did form part of the scenarios.

Despite the development of complex scale interactions, the lowest contribution for understanding scale dependencies (research challenge 7) is given by scientists of OZW. As with spatial scales, a more complex level of implementing temporal inertia and urgency (research challenge 8) does not reflect in a more positive evaluation in OZW. Again, RWR and IND score the highest for knowledge gain, although in RWR this issue was not explicitly analyzed. However, it should be mentioned that research challenges 7 and 8 are only covered by one response in the survey.
All case study teams evaluate the assessments as being beneficial for reflecting uncertainty (research challenge 9) despite a considerable range in responses. In OZW, the analysis of the abrupt change after the Tunisian revolution was perceived as highly relevant, hence, that of thresholds not sufficient. By contrast, researchers from IND admit to high capacity building related to thresholds for future research but feel there was a lack of analysis related to the security situation after the violent conflict in Mali.

\section{DISCUSSION}

\section{Strengths and limitations of the applied methods}

All of the case studies have complex sustainability problems originating from climate change, population dynamics, land degradation, and/or poor governance. They all involved research into sustainable development amid regional and global change using scenario assessments. The indicator set across all research challenges was designed to compare scenario assessments with respect to a range of aspects related to sustainability science. By comparing case studies, different ways of exploring research challenges in scenario assessments can be shown. This raises awareness of the complexity of sustainability problems, and of the variety of scenario approaches possible that are required to address them. Moreover, research challenges that are of concern across case studies, like the exploration of system thresholds in this study, can be exposed and may indicate the need for more research. Using different and/or more indicators would highlight additional aspects and is therefore encouraged. Comparing scenario assessments, for instance, in terms of contributing to the prioritization, assessment, and implementation of management options could bring additional insights for sustainability studies. 
Fig. 6. Comparison between the implementation of research challenges in the case studies evaluated by the researcher team (see Table 2) and the survey responses of local researchers on the perceived usefulness of scenario assessments to contribute to the research challenges (see Table A2.2 and Table A3.1). Boxes represent the median of the responses per research challenge and case study (n corresponds to the number of responses taken into account for each research challenge). The blue whiskers give the minimum and maximum response value for each research challenge. Filling lines represent the score of indicators evaluated by the researcher team (see Fig. 4). OZW = Oum Zessar watershed, RWR = Rwenzori region, IND = Inner Niger Delta, UTH = upper Thukela / uThukela basin.

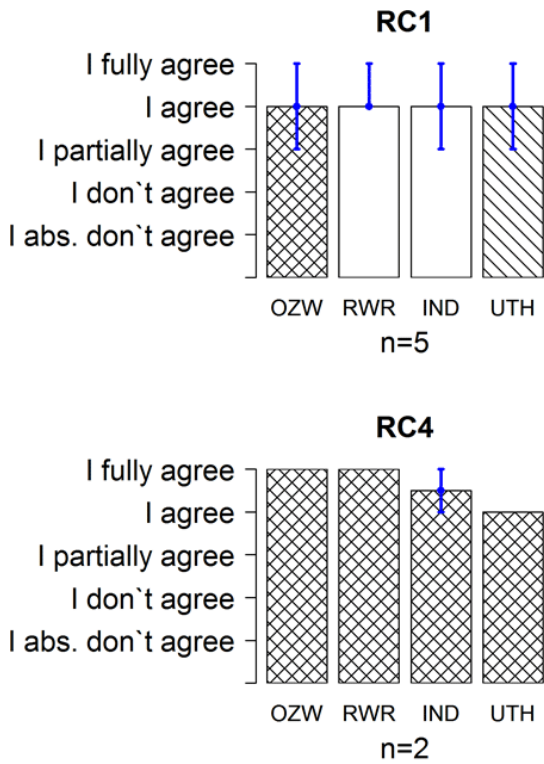

RC7

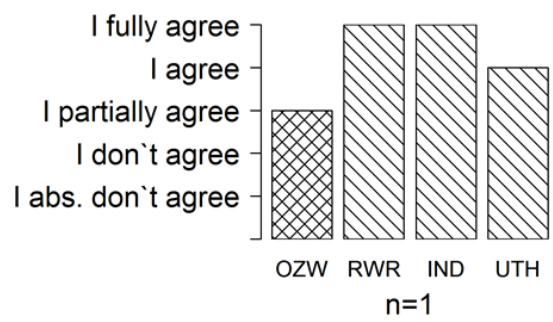

RC2

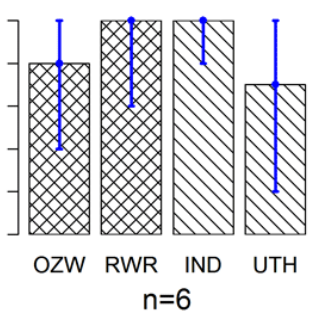

RC5

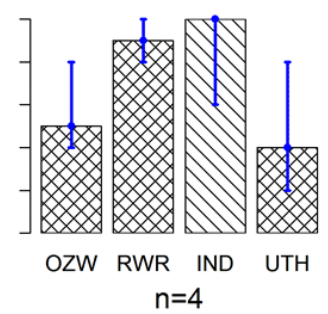

RC8

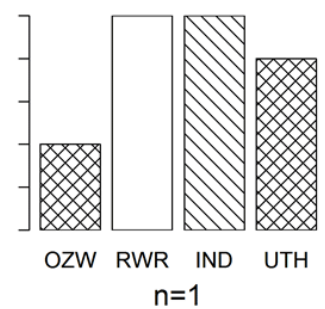

RC3

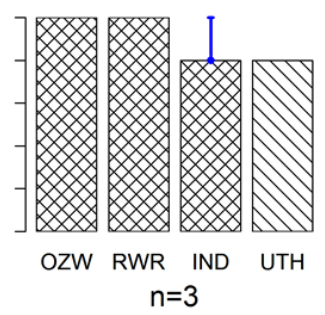

RC6

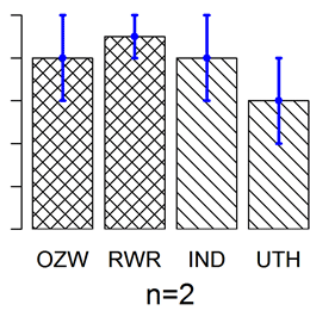

RC9

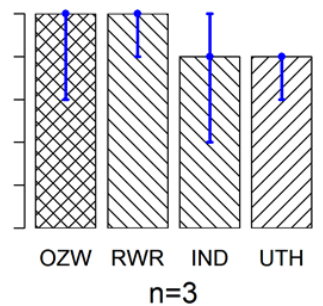

No indicator addressed $\quad \mathbb{F}$ First indicator addressed

Second indicator addressed Both indicators addressed

Transdisciplinary research processes are usually designed for a variety of goals and stakeholder compositions so that general evaluation schemes are difficult to develop (Walter et al. 2007, Hegger et al. 2012). We used four criteria to evaluate the potential of our research to bridge the divide of science and nonscience by means of a survey (credibility, salience, legitimacy, and capacity building) that have been applied in a number of studies before (e.g., Chaudhury et al. 2013, Kunseler et al. 2015). Comparing the results of the survey with the evaluation according to the framework of Swart et al. (2004) helped to verify benefits and shortcomings of the scenario assessments for advancing sustainability. A limitation in this regard comes from the small number of responses for some research challenges. Because research challenges 3, 4, and 9 intertwine, they were covered by overlapping response questions. Surveys are, moreover, prone to different response styles and if self- administered there is a risk of interpreting the questions or response selection differently. Both factors affect the validity of the results (Fowler 2013, Roberts 2016). Because of the small number of participants in the surveys and the mentioned limitations of surveys in general, a comparison between case studies must be treated with caution. Another potential weakness of the sampling procedure is the background of the researchers. Because of the range of knowledge, interests, interpretations, and expertise, and the norms for evaluating the credibility, legitimacy, and salience, the acceptance of produced knowledge varies among actors with different professional backgrounds (White et al. 2010, Kunseler et al. 2015). The majority of researchers of the survey had an environmental background, a tendency that was also observed in the workshops. An engagement of more stakeholders from social sciences and other groups could have enhanced the production of socially robust knowledge on complex 
sustainability problems, supported the development of research strategies to address them, and increased scientific, and societal, effects of the scenario assessments (Gibbons 1999, Raymond et al. 2010)

\section{Implementing the research challenges in the scenario approaches} The comparison of the four case studies shows that not all research challenges highlighted for sustainability science by Swart et al. (2004) were fully met. The most comprehensive case study was OZW, where all research challenges were addressed. The developed scenarios included qualitative and quantitative analysis and a number of stakeholders was actively engaged in the whole process.

The case studies used three strategies of knowledge integration (see Mollinga 2010): active engagement of stakeholders from different domains in qualitative exercises (OZW, RWR), a quantitative model-based analysis (IND, UTH, OZW), and the development of a model coupling framework (UTH). The main advantage of participatory approaches (OZW, RWR) was the possibility of integrating issues with the level of complexity and focus preferred by participants (see also Kok and van Delden 2009). Experienced shortcomings of qualitative approaches were the poor spatial explicitness and the difficulties of addressing climate change adequately, which hampers the qualitative assessment of management options. Similar to other studies, a difficulty in dealing with nonenvironmental drivers or factors such as governance was their translation from narratives into model input due to the required reduction in complexity (Walz et al. 2007, Mason-D'Croz et al. 2016) and the lack of time-series data to calibrate and validate the models in this regard.

The development of conceptual models such as the model coupling framework (UTH) in expert groups or concept maps in participatory processes (OZW, RWR) facilitated the selection and visualization of interactions between relevant system drivers and processes over a range of domains (see Reyers et al. 2015). As is discussed by Birkmann et al. (2015), the benefit of using complex numerical models was the level of detail and the possibility of simulating climate change effects. Drawbacks in this regard were the restriction to quantifiable research questions and data requirements.

Regarding the research challenges, three research needs were expressed across case studies - namely, to investigate system thresholds, to determine spatially explicit local information, and to analyze political and governmental factors.

All case studies required relevant system thresholds to ensure regional sustainability. This experience is reflected in the growing discussion to define a safe operating space for humanity by studying planetary boundaries (e.g., Steffen et al. 2015). In line with Dearing et al. (2014), we argue that boundaries should be developed also for the regional scale where natural resources are mostly managed in order to increase policy relevance.

The case studies analyzed dependencies from external drivers but also needed spatially explicit local information for addressing upstream-downstream issues for example, or planning local adaptation measures. In this regard, the UTH approach for analyzing spatially explicit ecosystem service changes is promising. Producing spatially explicit information as well as linking information across scales has been widely recognized as increasing policy relevance (e.g., Godar et al. 2015, Capitani et al. 2016), but this requires good data availability, resources, and the implementation of appropriate assessment tools, which were not necessarily available in all case studies.

Three out of the four case studies show that important uncertainties arise from political or governmental issues; a finding that is also reported by Kok et al. (2007) and Chaudhury et al. (2013). The case studies considered power relations in governance systems, especially land tenure systems, essential for understanding sustainability problems. These were subject of analysis in OZW and RWR. According to Berbés-Blázquez et al. (2016) ecosystem assessments need a stronger focus on power relations because they effect the management and the access to natural resources and thus the social and regional equity in gains and losses from producing ecosystem services. Power dynamics and the inherent power relations of the iterative decision-making process moreover may contribute to difficulties in implementing scientific knowledge in policy (Cáceres et al. 2016). The role of governance for successful resource management has long been recognized (e.g., Acheson 2006) and its better representation in quantitative scenarios was demanded (van Ruijven et al. 2014). There are attempts to quantify dampening effects of weak governance on policy implementation (McNeill et al. 2014) and the conditions that influence the effectiveness of environmental regimes (de Vos et al. 2013). However, the most common approach has been to translate different specifications of governance parameters into model input (e.g., Berkhout et al. 2002) because numerical models are less equipped to analyze governmental issues (de Vos et al. 2013). To date, (participatory) qualitative approaches are therefore probably the most adequate for in-depth analyses of governmental and political issues and their possible developments in the future.

A benefit that could not be clearly attributed to one of the research challenges is that scenario development reveals potential cognitive biases in the judgement of participants (see Tversky and Kahnemann 1974). The OZW team was more reluctant to develop unpleasant scenarios because of the long and unstable transition period after the revolution; an experience that has also been noted by Schoemaker (1993) and Kok et al. (2007). Recognizing the influence of such cognitive biases on scenario development is important for studying potential adaptation measures that should be robust to a range of possible futures (see Metzger et al. 2010). According to Meissner and Wulf (2013), scenario planning does not only reveal but also decreases cognitive biases and therefore improves decision quality; however, this potential benefit needs further analysis.

Scenarios can be more than just a tool for analyzing a range of research challenges. Focusing on interlinkages between a set of research challenges can deliver additional insights to manage sustainable transition. De Vries et al. (2009), for instance, analyzed the connection between different worldviews (values, interests) of people and their human choices and how to translate these into scenarios. The experiences of this study suggest a combination of temporal inertia and urgency and thresholds for analysis. The case studies developed either static or dynamic future trajectories, and both benefit from using thresholds. Analyzing static trajectories with fixed management/driver assumptions, allows the identification of different points in time when the system of analysis passes a threshold and reaches an 
unsupportable state. Analyzing the impact of new dams and reservoirs in this way, such as done in IND, can be directly relevant to policy. The development of dynamic management pathways benefits from thresholds in order to adapt driver assumptions once a critical value is reached. In doing so, short-term decision making needs and long-term climate change effects can be taken into account simultaneously (see Kok et al. 2007).

\section{Evaluation of scenario assessments through local researchers}

Combining the comparison of the implementation of the sustainability research challenges with the survey of local researchers made evident that the singularity of every case study influences the type of research challenges and the way they were addressed, but may not directly affect the perceived efficiency of the scenario assessments. The poor agreement of the evaluation with the score of indicators in some research challenges might be partly attributed to the mentioned methodological shortcomings but also to case study-specific reasons.

Reasons for the perceived moderate usefulness of the OZW and UTH assessments encompass the difficulty to understand, to agree on, and to adapt the complex scenario approaches to local contexts. In OZW, the detailed and long process of developing participatory scenarios (see also Kok et al. 2007 and Hatzilacou et al. 2007) might have compromised the transparency of the results so that it was hard for end-users to grasp the complexity of scenarios. Rounsevell and Metzger (2010) discuss the difficulty of validating complex qualitative scenarios and this might have contributed to the lack of plausibility and consistency perceived by the OZW scientists (see also Hatzilacou et al. 2007). Model coupling in UTH was a long and IT-driven process and was also not easy to follow for the people who were not involved in this particular process or from this research discipline.

For RWR, it was the first time that the case study team had been involved in such work and therefore the start of science-practice collaboration on INRM. The main reason for the very positive survey responses is that the process likely allowed for the enhancement of basic knowledge regarding many issues and brought together key stakeholders and decision makers.

Whereas RWR developed the big picture as a first step, a detailed analysis of the system's response to selected natural and societal pressures was conducted in IND. For IND, the AFROMAISON project was a follow-up activity of the WETWIN project (Johnston et al. 2013, Shamir and Verhoeven 2013) where important tools (the SWIM model, Liersch et al. 2013) and the broader context had already been worked out (qualitative assessments, see Zsuffa and Cools 2011). Such iterative scenario assessments can contribute or complete information required for evidence-based decision making (see Schoemaker 1995, Wilkinson and Eidinow 2008, Mahmoud et al. 2009). This indicates that breaking down the system complexity into smaller parts can be required because of the ongoing lack of system understanding, even for clearly defined interactions between society and natural systems, as in IND.

\section{SUMMARY AND CONCLUSIONS}

Scenario assessments have to address complex human-natural systems when studying sustainability problems amid regional and global change. They are faced with the challenge of recognizing the inherent complexity of system behavior and to reduce but not oversimplify it for analysis. There is a need to integrate knowledge and stakeholders into the process and to raise awareness on complexity but also to make it applicable for end users. Scenario assessments that are well-tailored to the needs of the policy environment can provide an effective support for society for making decisions about complex sustainability problems. We aim with this study to make a contribution to such an effort.

We evaluated four case studies that used scenarios in their sustainability research in the context of INRM. The evaluation combined an analysis of whether and how the case studies implemented Swart et al.'s (2004) research challenges of sustainability and a survey of local researchers to discover the scientific effects of the scenario assessments. The survey was carried out approximately one year after the local projects were finalized.

The limitations of this study are mainly related to the sampling procedures to assess the potential of our research to bridge the divide of science and nonscience. The survey was limited to a small number of local researchers, mainly from natural sciences. It would be extremely valuable to invite feedback from a higher number of local stakeholders and to include the perceptions of different stakeholder groups in future research. Such evaluations could contribute to better understanding of future research needs in a specific decision context as well as opportunities and barriers of implementing research in policy.

One outcome of the survey showed that the comprehensiveness of a scenario assessment in analyzing research challenges does not necessarily mean that it is perceived as useful by scenario users. The application of complex approaches, as in OZW or UTH, need to be carefully planned because they are very resource and time intensive. The expected lengthy process has to be coordinated with policy schedules and the amount of information produced made sufficiently transparent, specific, and usable.

The findings of this study encourage the development of holistic narratives with active stakeholder participation (OZW, RWR) for analyzing new and unknown socio-political situations with potentially high impacts on many stakeholder groups. This facilitates the selection of key processes and indicators for more specific future research. A good overall system understanding (because of earlier research activities, comprehensive cause-effect diagrams, and on the condition that no fundamental system changes occur) allows the system of analysis to be broken down into its components. This is a precondition for studying specific research challenges in sufficient detail. Moreover, the interlinkages of research challenges should be analyzed to increase the understanding of processes related to sustainability problems.

This study adds to the current debate on defining environmental limits for regional human-natural systems. Using thresholds strongly supports the development of useful and long-term management strategies and helps to show temporal mismatches between different drivers, which are generated when short-term management needs confront research recommendations on longterm climate change effects or sustainability goals.

Regional scenarios build a bridge between the national (or higher) scale, where policies are often formulated, and the local scale, where adaptation options are planned and implemented. Their 
relevance is likely to increase if scales are linked by providing spatially explicit outcomes and/or bringing subnational perspectives to higher levels.

Although the findings of this study cannot be generalized given the small number of case studies, the results highlight that individual, locally adapted scenario procedures usually lead to scenarios that are perceived as useful by scenario participants and users. A scenario building process has to be flexible, with a strong connection to previous activities related to the key issue, and make use of data and earlier collaborative work.

Responses to this article can be read online at: http://www.ecologyandsociety.org/issues/responses. php/9728

\section{Acknowledgments:}

The research leading to these results has received funding from the European Union Seventh Framework Programme (FP7/20072013 ) under grant agreement $n^{\circ} 266379$. It was carried out as part of the AFROMAISON project. Finally, we would like to thank the anonymous reviewers for their valuable contributions to improving this paper. The publication of this article was partially funded by the Open Access Fund of the Leibniz Association. Ilona M. Otto gratefully acknowledges research funding from the Earth League's EarthDoc Program.

\section{LITERATURE CITED}

Acheson, J. M. 2006. Institutional failure in resource management. Annual Review of Anthropology 35:117-134. http:// dx.doi.org/10.1146/annurev.anthro.35.081705.123238

Adger, W. N., H. Eakin, and A. Winkels. 2009. Nested and teleconnected vulnerabilities to environmental change. Frontiers in Ecology and the Environment 7(3):150-157. http://dx.doi. org/10.1890/070148

African Development Bank (AfDB). 2013. Annual development effectiveness: review 2013. Towards sustainable growth for Africa. African Development Bank, Abidjan, Côte d'Ivoire. [online] URL: https://www.afdb.org/fileadmin/uploads/afdb/Documents/ Project-and-Operations/ADER- $\% 20$ Annual $\% 20$ Development $\%$ 20Effectiveness $\% 20$ Review $\% 202013$.pdf

African Development Bank and World Wide Fund (AfDB and WWF). 2015. African ecological futures report. African Development Band and WWF Regional Office for Africa, Nairobi, Kenya. [online] URL: http://wwf.panda.org/who_we are/ wwf offices/regional office for africa/african ecological futures/

Aich, V., S. Liersch, T. Vetter, S. Huang, J. Tecklenburg, P. Hoffmann, H. Koch, S. Fournet, V. Krysanova, E. N. Müller, and F. F. Hattermann. 2014. Comparing impacts of climate change on streamflow in four large African river basins. Hydrology and Earth System Sciences 18(4):1305-1321. http://dx.doi.org/10.5194/ hess-18-1305-2014

Albert, C. 2013. Participatory scenarios in developing and implementing long-term policies. Pages 200-218 in B.
Siebenhüner, M. Arnold, K. Eisenack, and K. Jacob, editors. Long-term governance for socio-ecological change. Routledge, London, UK.

Alcamo, J., and T. Henrichs. 2008. Towards guidelines for environmental scenario analysis. Pages 13-35 in J. Alcamo, editor. Environmental futures: the practice of environmental scenario analysis. First edition. Elsevier, Amsterdam, The Netherlands. http://dx.doi.org/10.1016/S1574-101X(08)00402-X

Alcamo, J., D. van Vuuren, C. Ringler, W. Cramer, T. Masui, J. Alder, and K. Schulze. 2005. Changes in nature's balance sheet: model-based estimates of future worldwide ecosystem services. Ecology and Society 10(2):19. http://dx.doi.org/10.5751/ ES-01551-100219

Ash, N. 2010. Ecosystems and human well-being: a manual for assessment practitioners. Island Press, Washington, D.C., USA.

Atukwatse, P. B., C. Busiinge, F. Tuhaise, F. Ahaisibwe, Y. Tumwine, F. Kaahwa, and M. Muhumuza. 2012. Stuck in the mist: contextual analysis of the conflicts in the Rwenzori region. Kabarole Research and Resource Centre, Fort-Portal, Uganda. [online] URL: http://krcuganda.org/?wpfb dl=101

Baguwemu, A., F. Onyai, R. Kaggwa, O. Kashemeire, J. M. Atwembembeire, S. Magero, and J. P. Olemo, and G. I. Odeke. 2013. The state of Uganda population report 2013: population and social transformation: addressing the needs of special interest groups. Population Secretariat, Ministry of Finance, Planning and Economic Development, The Republic of Uganda, Kampala, Uganda. [online] URL: http://www.ilo.org/surveydata/ index.php/catalog/988/download/6273

Belcher, B. M., K. E. Rasmussen, M. R. Kemshaw, and D. A. Zornes. 2016. Defining and assessing research quality in a transdisciplinary context. Research Evaluation 25(1):1-17. http:// dx.doi.org/10.1093/reseval/rvv025

Berbés-Blázquez, M., J. A. González, and U. Pascual. 2016. Towards an ecosystem services approach that addresses social power relations. Current Opinion in Environmental Sustainability 19:134-143. http://dx.doi.org/10.1016/j.cosust.2016.02.003

Berkhout, F., J. Hertin, and A. Jordan. 2002. Socio-economic futures in climate change impact assessment: using scenarios as 'learning machines.' Global Environmental Change 12(2):83-95. http://dx.doi.org/10.1016/S0959-3780(02)00006-7

Biggs, R., C. Raudsepp-Hearne, C. Atkinson-Palombo, E. Bohensky, E. Boyd, G. Cundill, H. Fox, S. Ingram, K. Kok, S. Spehar, M. Tengö, D. Timmer, and M. Zurek. 2007. Linking futures across scales: a dialog on multiscale scenarios. Ecology and Society 2(1):17. http://dx.doi.org/10.5751/ES-02051-120117

Birkmann, J., S. L. Cutter, D. S. Rothman, T. Welle, M. Garschagen, B. van Ruijven, B. O'Neill, B. L. Preston, S. Kienberger, O. D. Cardona, T. Siagian, D. Hidayati, N. Setiadi, C. R. Binder, B. Hughes, and R. Pulwarty. 2015. Scenarios for vulnerability: opportunities and constraints in the context of climate change and disaster risk. Climatic Change 133(1):53-68. http://dx.doi.org/10.1007/s10584-013-0913-2

Blignaut, J., M. Mander, R. Schulze, M. Horan, C. Dickens, C. Pringle, K. Mavundla, I. Mahlangu, A. Wilson, M. McKenzie, and S. McKean. 2010. Restoring and managing natural capital 
towards fostering economic development: evidence from the Drakensberg, South Africa. Ecological Economics 69 (6):1313-1323. http://dx.doi.org/10.1016/j.ecolecon.2010.01.007

Busch, G. 2006. Future European agricultural landscapes: What can we learn from existing quantitative land use scenario studies? Agriculture, Ecosystems \& Environment 114(1):121-140. http://dx. doi.org/10.1016/j.agee.2005.11.007

Cáceres, D. M., F. Silvetti, and S. Díaz. 2016. The rocky path from policy-relevant science to policy implementation: a case study from the South American Chaco. Current Opinion in Environmental Sustainability 19:57-66. http://dx.doi.org/10.1016/ j.cosust.2015.12.003

Capitani, C., K. Mukama, B. Mbilinyi, I. O. Malugu, P. K. T. Munishi, N. D. Burgess, P. J. Platts, S. M. Sallu, and R. Marchant. 2016. From local scenarios to national maps: a participatory framework for envisioning the future of Tanzania. Ecology and Society 21(3):4. http://dx.doi.org/10.5751/ES-08565-210304

Cash, D., W. C. Clark, F. Alcock, N. M. Dickson, N. Eckley, and J. Jäger. 2002. Salience, credibility, legitimacy and boundaries: linking research, assessment and decision making. KSG Working Papers Series RWP02-046. John F. Kennedy School of Government, Cambridge, Massachusetts, USA. http://dx.doi. org/10.2139/ssrn.372280

Chaudhury, M., J. Vervoort, P. Kristjanson, P. Ericksen, and A. Ainslie. 2013. Participatory scenarios as a tool to link science and policy on food security under climate change in East Africa. Regional Environmental Change 13(2):389-398. http://dx.doi. org/10.1007/s10113-012-0350-1

Clark, W. C., T. P. Tomich, M. van Noordwijk, D. Guston, D. Catacutan, N. M. Dickson, and E. McNie. 2016. Boundary work for sustainable development: natural resource management at the Consultative Group on International Agricultural Research (CGIAR). Proceedings of the National Academy of Sciences of the United States of America 113(17):4615-4622. http://dx.doi. org/10.1073/pnas.0900231108

Clarke, N., J.-C. Bizimana, Y. Dile, A. Worqlul, J. Osorio, B. Herbst, J. W. Richardson, R. Srinivasan, T. J. Gerik, J. Williams, C. A. Jones, and J. Jeong. 2017. Evaluation of new farming technologies in Ethiopia using the integrated decision support system (IDSS). Agricultural Water Management 180:267-279. http://dx.doi.org/10.1016/j.agwat.2016.07.023

Das, S., J. A. Priess, and C. Schweitzer. 2012. Modelling regional scale biofuel scenarios - a case study for India. Global Change Biology Bioenergy 4(2):176-192. http://dx.doi.org/10.1111/ j.1757-1707.2011.01114.X

De Vos, M. G., P. H. M. Janssen, M. T. J. Kok, S. Frantzi, E. Dellas, P. Pattberg, A. C. Petersen, and F. Biermann. 2013. Formalizing knowledge on international environmental regimes: a first step towards integrating political science in integrated assessments of global environmental change. Environmental Modelling \& Software 44:101-112. http://dx.doi.org/10.1016/j. envsoft.2012.08.004

De Vries, B. J., and A. C. Petersen. 2009. Conceptualizing sustainable development: an assessment methodology connecting values, knowledge, worldviews and scenarios. Ecological
Economics 68(4):1006-1019. http://dx.doi.org/10.1016/j. ecolecon.2008.11.015

Dearing, J. A., R. Wang, K. Zhang, J. G. Dyke, H. Haberl, M. S. Hossain, P. G. Langdon, T. M. Lenton, K. Raworth, S. Brown, J. Carstensen, M. J. Cole, S. E. Cornell, T. P. Dawson, C. P. Doncaster, F. Eigenbrod, M. Flörke, E. Jeffers, A. W. Mackay, B. Nykvist, and G. M. Poppy. 2014. Safe and just operating spaces for regional social-ecological systems. Global Environmental Change 28:227-238. http://dx.doi.org/10.1016/j.gloenvcha.2014.06.012

Department of Environmental Affairs and Tourism. 2006. South Africa environment outlook: a report on the state of environment. Department of Environmental Affairs and Tourism, Pretoria, Sout Africa.

Department of Water Affairs and Forestry (DWAF). 2004. Internal strategic perspective: Thukela water management area. Report No. P WMA 07/000/00/0304. DWAF, Pretoria, South Africa.

Dessu, S. B., and A. M. Melesse. 2013. Impact and uncertainties of climate change on the hydrology of the Mara River basin, Kenya/Tanzania. Hydrological Processes 27:2973-2986.

Fabricius, C., R. J. Scholes, and G. Cundill. 2006. Mobilising knowledge for ecosystem management. Pages 165-182 in W. V. Reid, F. Berkes, T. J. Wilbanks, and D. Capistrano, editors. Bridging scales and knowledge systems: concepts and applications in ecosystem assessment. Island Press, Washington, D.C., USA.

Fader, M., D. Gerten, M. Krause, W. Lucht, and W. Cramer. 2013. Spatial decoupling of agricultural production and consumption: quantifying dependences of countries on food imports due to domestic land and water constraints. Environmental Research Letters 8(1):14046. http://dx.doi.org/10.1088/1748-9326/8/1/014046

Food and Agriculture Organization (FAO). 2015. Regional overview of food insecurity: African food security prospects brighter than ever. FAO, Accra, Ghana.

Fowler, F. J. 2013. Survey research methods. Fifth edition. Sage, Los Angeles, California, USA.

Gibbons, M. 1999. Science's new social contract with society. Nature 402:C81-C84. http://dx.doi.org/10.1038/35011576

Godar, J., U. M. Persson, E. J. Tizado, and P. Meyfroidt. 2015. Towards more accurate and policy relevant footprint analyses: tracing fine-scale socio-environmental impacts of production to consumption. Ecological Economics 112:25-35. http://dx.doi. org/10.1016/j.ecolecon.2015.02.003

Guan, K., B. Sultan, M. Biasutti, C. Baron, and D. B. Lobell. 2015. What aspects of future rainfall changes matter for crop yields in West Africa? Geophysical Research Letters 42 (19):8001-8010. http://dx.doi.org/10.1002/2015GL063877

Hatzilacou, D., G. Kallis, A. Mexa, H. Coccosis, and E. Svoronou. 2007. Scenario workshops: a useful method for participatory water resources planning? Water Resources Research 43(6):1-12. http://dx.doi.org/10.1029/2006WR004878

Hegger, D., M. Lamers, A. van Zeijl-Rozema, and C. Dieperink. 2012. Conceptualising joint knowledge production in regional climate change adaptation projects: success conditions and levers for action. Environmental Science \& Policy 18:52-65. http://dx.doi. org/10.1016/j.envsci.2012.01.002 
Herrero, M., P. K. Thornton, A. Bernués, I. Baltenweck, J. Vervoort, J. van de Steeg, S. Makokha, M. T. van Wijk, S. Karanja, M. C. Rufino, and S. J. Staal. 2014. Exploring future changes in smallholder farming systems by linking socio-economic scenarios with regional and household models. Global Environmental Change 24:165-182. http://dx.doi.org/10.1016/j.gloenvcha.2013.12.008

Hertzog, T., A. Adamczewski, F. Molle, J.-C. Poussin, and J.-Y. Jamin. 2012. Ostrich-like strategies in Sahelian sands? Land and water grabbing in the Office du Niger, Mali. Water Alternatives 5 (2):304-321.

Hulme, M., and S. Dessai. 2008. Predicting, deciding, learning: can one evaluate the 'success' of national climate scenarios? Environmental Research Letters 3(4):45013. http://dx.doi. org/10.1088/1748-9326/3/4/045013

Intergovernmental Science-Policy Platform on Biodiversity and Ecosystem Services (IPBES). 2016. Summary for policymakers of the methodological assessment of scenarios and models of biodiversity and ecosystem services of the Intergovernmental Science-Policy Platform on Biodiversity and Ecosystem Services. S. Ferrier, K. N. Ninan, P. Leadley, R. Alkemade, L.A. Acosta, H. R. Akçakaya, L. Brotons, W. Cheung, V. Christensen, K. A. Harhash, J. Kabubo-Mariara, C. Lundquist, M. Obersteiner, H. Pereira, G. Peterson, R. Pichs-Madruga, N. H. Ravindranath, C. Rondinini, B. Wintle, editors. Secretariat of the Intergovernmental Science-Policy Platform on Biodiversity and Ecosystem Services, Bonn, Germany.

Jalloh, A., H. Roy-Macauley, and P. Sereme. 2012. Major agroecosystems of West and Central Africa: brief description, species richness, management, environmental limitations and concerns. Agriculture, Ecosystems \& Environment 157:5-16. http://dx.doi. org/10.1016/j.agee.2011.11.019

Johnston, R., J. Cools, S. Liersch, S. Moradet, C. Murgue, M. Mahieu, I. Zsuffa, and G. Uytendaelle. 2013. WETwin: a structured approach to evaluating wetland management options in data-poor contexts. Environmental Science \& Policy 34:3-17. http://dx.doi.org/10.1016/j.envsci.2012.12.006

Kabaseke, C., J. L. R. Birungi, and R. Lemmons. 2012. Mpanga catchment area baseline assessment report: involving local communities in preparing a long term climate change and integrated water resource management action plan to enhance their adaptive capacity to climate change, and integrate improved water management in the Mpanga catchment area of the Nile basin in Uganda. Protos, Ghent, Belgium.

Kassie, B. T., S. Asseng, R. P. Rotter, H. Hengsdijk, A. C. Ruane, and M. K. van Ittersum. 2015. Exploring climate change impacts and adaptation options for maize production in the Central Rift Valley of Ethiopia using different climate change scenarios and crop models. Climatic Change 129(1-2):145-158. http://dx.doi. org/10.1007/s10584-014-1322-X

Kates, R. W., W. C. Clark, R. Corell, J. M. Hall, C. C. Jaeger, I. Lowe, J. J. McCarthy, H. J. Schellnhuber, B. Bolin, N. M. Dickson, S. Faucheux, G. C. Gallopin, A. Grübler, B. Huntley, J. Jäger, N. S. Jodha, R. E. Kasperson, A. Mabogunje, P. Matson, H. Mooney, B. Moore, T. O'Riordan, and U. Svedin. 2001. Sustainability science. Science 292(5517):641-642. http://dx.doi.org/10.1126/ science. 1059386
Koch, H., S. Liersch, and F. F. Hattermann. 2013. Integrating water resources management in eco-hydrological modelling. Water Science \& Technology 67(7):1525-1533. http://dx.doi. org/10.2166/wst.2013.022

Kok, K., R. Biggs, and M. Zurek. 2007. Methods for developing multiscale participatory scenarios: insights from southern Africa and Europe. Ecology and Society 13(1):8. http://dx.doi. org/10.5751/ES-01971-120108

Kok, K., and H. van Delden. 2009. Combining two approaches of integrated scenario development to combat desertification in the Guadalentín watershed, Spain. Environment and Planning B: Urban Analytics and City Science 36(1):49-66. http://dx.doi. org/10.1068/b32137

Kok, M. T. J., K. Kok, G. D. Peterson, R. Hill, J. Agard, and S. R. Carpenter. 2017. Biodiversity and ecosystem services require IPBES to take novel approach to scenarios. Sustainability Science 12:177-181. http://dx.doi.org/10.1007/s11625-016-0354-8

Kotler, P., R. Berger, and N. Bickhoff. 2010. The quintessence of strategic management: what you really need to know to survive in business. Springer, Berlin, Germany. http://dx.doi.

org/10.1007/978-3-642-14544-5

Kabarole Research and Resource Center (KRC). 2012. Rwenzori regional development framework. KRC, Fort-Portal, Uganda.

Krysanova, V., F. Hattermann, S. Huang, C. Hesse, T. Vetter, S. Liersch, H. Koch, and Z. W. Kundzewicz. 2015. Modelling climate and land-use change impacts with SWIM: lessons learnt from multiple applications. Hydrological Sciences Journal 60:606-635. http://dx.doi.org/10.1080/02626667.2014.925560

Krysanova, V., F. Hattermann, and F. Wechsung. 2005. Development of the ecohydrological model SWIM for regional impact studies and vulnerability assessment. Hydrological Processes 19(3):763-783. http://dx.doi.org/10.1002/hyp.5619

Krysanova, V., D.-I. Müller-Wohlfeil, and A. Becker. 1998. Development and test of a spatially distributed hydrological/ water quality model for mesoscale watersheds. Ecological Modelling 106(2-3):261-289. http://dx.doi.org/10.1016/S0304-3800 (97)00204-4

Kunseler, E.-M., W. Tuinstra, E. Vasileiadou, and A. C. Petersen. 2015. The reflective futures practitioner: Balancing salience, credibility and legitimacy in generating foresight knowledge with stakeholders. Futures 66:1-12. $\underline{\text { http://dx.doi.org/10.1016/j. }}$ futures.2014.10.006

Liersch, S., J. Cools, B. Kone, H. Koch, M. Diallo, J. Reinhardt, S. Fournet, V. Aich, and F. Hattermann. 2013. Vulnerability of rice production in the Inner Niger Delta to water resources management under climate variability and change. Environmental Science \& Policy 34:18-33. http://dx.doi.org/10.1016/j.envsci.2012.10.014

Ludi, E., L. Jones, and S. Levine. 2012. Changing focus? How to take adaptive capacity seriously: evidence from Africa shows that development interventions could do more. ODI Briefing Paper 71. Overseas Development Institute, London, UK. http://dx.doi. org $/ 10.2139 /$ ssrn. 2782343

Mahmoud, M., Y. Liu, H. Hartmann, S. Stewart, T. Wagener, D. Semmens, R. Stewart, H. Gupta, D. Dominguez, F. Dominguez, 
D. Hulse, R. Letcher, B. Rashleigh, C. Smith, R. Street, J. Ticehurst, M. Twery, H. van Delden, R. Waldick, D. White, and L. Winter. 2009. A formal framework for scenario development in support of environmental decision-making. Environmental Modelling \& Software 24(7):798-808. http://dx.doi.org/10.1016/j. envsoft.2008.11.010

Malinga, R., L. J. Gordon, R. Lindborg, and G. Jewitt. 2013. Using participatory scenario planning to identify ecosystem services in changing landscapes. Ecology and Society 18(4):10. http://dx.doi.org/10.5751/ES-05494-180410

Mason-D'Croz, D., J. Vervoort, A. Palazzo, S. Islam, S. Lord, A. Helfgott, P. Havlík, R. Peou, M. Sassen, M. Veeger, A. van Soesbergen, A. P. Arnell, B. Stuch, A. Arslan, and L. Lipper. 2016. Multi-factor, multi-state, multi-model scenarios: exploring food and climate futures for Southeast Asia. Environmental Modelling \& Software 83:255-270. http://dx.doi.org/10.1016/j.envsoft.2016.05.008

McNeill, D., M. Bursztyn, N. Novira, S. Purushothaman, R. Verburg, and S. Rodrigues-Filho. 2014. Taking account of governance: the challenge for land-use planning models. Land Use Policy 37:6-13. http://dx.doi.org/10.1016/j.landusepol.2012.09.006

Meissner, P., and T. Wulf. 2013. Cognitive benefits of scenario planning: its impact on biases and decision quality. Technological Forecasting and Social Change 80(4):801-814. http://dx.doi. org/10.1016/j.techfore.2012.09.011

Metzger, M. J., M. D. A. Rounsevell, H. van den Heiligenberg, M. Pérez-Soba, and P. Soto Hardiman. 2010. How personal judgment influences scenario development: an example for future rural development in Europe. Ecology and Society 15(2):5. http:// dx.doi.org/10.5751/ES-03305-150205

Mollinga, P. P. 2010. Boundary work and the complexity of natural resources management. Crop Science 50(Supplement 1): S1-S9. http://dx.doi.org/10.2135/cropsci2009.10.0570

Mueller, N. D., J. S. Gerber, M. Johnston, D. K. Ray, N. Ramankutty, and J. A. Foley. 2012. Closing yield gaps through nutrient and water management. Nature 490(7419):254-257. http://dx.doi.org/10.1038/nature11420

Müller, C. 2013. African lessons on climate change risks for agriculture. Annual Review of Nutrition 33:395-411. http://dx.doi. org/10.1146/annurev-nutr-071812-161121

National Environment Management Authority (NEMA). 2010. State of the environment report for Uganda 2010. NEMA, Kampala, Uganda. [online] URL: http://www.nemaug.org/ reports/national state report 2010.pdf

Nesheim, I., P. Reidsma, I. Bezlepkina, R. Verburg, M. A. Abdeladhim, M. Bursztyn, L. Chen, Y. Cissé, S. Feng, P. Gicheru, H. Jochen König, N. Novira, S. Purushothaman, S. RodriguesFilho, and M. Sghaier. 2014. Causal chains, policy trade offs and sustainability: analysing land (mis)use in seven countries in the South. Land Use Policy 37:60-70. http://dx.doi.org/10.1016/j. landusepol.2012.04.024

Niang, I., O. C. Ruppel, M. A. Abdrabo, A. Essel, C. Lennard, J. Padgham, and P. Urquhart. 2014. Africa. Pages 1199-1266 in V. F. C. Barros, C. B. Field, D. J. Dokken, M. D. Mastrandrea, K. J. Mach, T. E. Bilir, M. Chatterjee, K. L. Ebi, Y. O. Estrada, R. C. Genova, B. Girma, E. S. Kissel, A. N. Levy, S. MacCracken,
P. R. Mastrandrea, and L. L. White, editors. Climate change 2014: impacts, adaptation, and vulnerability. Part B: regional aspects. Contribution of Working Group II to the Fifth Assessment Report of the Intergovernmental Panel on Climate Change. Cambridge University Press, Cambridge, UK.

Niemeijer, D., and R. S. de Groot. 2008. A conceptual framework for selecting environmental indicator sets. Ecological Indicators 8 (1):14-25. http://dx.doi.org/10.1016/j.ecolind.2006.11.012

Niger Basin Authority (NBA). 2007. Elaboration of an action plan for the sustainable development of the Niger Basin: Phase 2 master plan for the development and management. NBA, Niamey, Niger. [online] URL: http://www.abn.ne/images/documents/textes/ padd/phase 2 en.pdf

Omrani, N., and D. Burger. 2012. Water management issues in Southern Tunisia under a climate change context. Pages 225-235 in W. Leal Filho, editor. Climate change and the sustainable use of water resources. Springer-Verlag, Berlin, Germany. http://dx.doi. org/10.1007/978-3-642-22266-5 14

Osbahr, H., C. Twyman, W. N. Adger, and D. S. G. Thomas. 2010. Evaluating successful livelihood adaptation to climate variability and change in Southern Africa. Ecology and Society 15(2):27. http://dx.doi.org/10.5751/ES-03388-150227

Pahl-Wostl, C. 2007. The implications of complexity for integrated resources management. Environmental Modelling \& Software 22(5):561-569. http://dx.doi.org/10.1016/j.envsoft.2005.12.024

Pahl-Wostl, C. 2008. Participation in building environmental scenarios. Pages 105-122 in J. Alcamo, editor. Environmental futures: the practice of environmental scenario analysis. First edition. Elsevier, Amsterdam, The Netherlands. http://dx.doi. org/10.1016/S1574-101X(08)00405-5

Peters, D. P. C., P. M. Groffman, K. J. Nadelhoffer, N. B. Grimm, S. L. Collins, W. K. Michener, and M. A. Huston. 2008. Living in an increasingly connected world: a framework for continentalscale environmental science. Frontiers in Ecology and the Environment 6(5):229-237. http://dx.doi.org/10.1890/070098

Pilz, T. 2013. Influence of climate change and management on water availability and erosion in a meso-scale catchment in South Africa. Thesis, University of Potsdam, Potsdam, Germany.

Priess, J. A., C. Schweitzer, F. Wimmer, O. Batkhishig, and M. Mimler. 2011. The consequences of land-use change and water demands in Central Mongolia. Land Use Policy 28:4-10. http:// dx.doi.org/10.1016/j.landusepol.2010.03.002

Raskin, P., T. Banuri, G. Gallopín, P. Gutman, A. Hammond, R. Kates, and R. Swart. 2002. Great transition: the promise and lure of the times ahead. a report of the Global Scenario Group. Stockholm Environment Institute, Tellus Institute, Boston, Massachusetts, USA. [online] URL: http://www.greattransition. org/documents/Great Transition.pdf

Raskin, P., E. Hansen, Z. Zhu, M. Iwra, and D. Stavisky. 1992. Simulation of water supply and demand in the Aral Sea region. Water International 17(55-67). http://dx.doi.org/10.1080/025080$\underline{69208686127}$

Raymond, C. M., I. Fazey, M. S. Reed, L. C. Stringer, G. M. Robinson, and A. C. Evely. 2010. Integrating local and scientific 
knowledge for environmental management. Journal of Environmental Management 91(8):1766-1777. http://dx.doi. org/10.1016/j.jenvman.2010.03.023

Reyers, B., J. L. Nel, P. J. O'Farrell, N. Sitas, and D. C. Nel. 2015. Navigating complexity through knowledge coproduction: mainstreaming ecosystem services into disaster risk reduction. Proceedings of the National Academy of Sciences of the United States of America 112(24):7362-7368. http://dx.doi.org/10.1073/ pnas. 1414374112

Roberts, C. 2016. Response styles in surveys: understanding their causes and mitigating their impact on data quality. Pages 579-596 in C. Wolf, D. Joye, T. W. Smith, and Y.-C. Fu, editors. The Sage handbook of survey methodology. Sage, Los Angeles, California, USA. http://dx.doi.org/10.4135/9781473957893.n36

Romagny, B., H. Guillaume, H. Ben Ouezdou, and S. Palluault. 2004. Ressources en eau, usages et concurrences dans la Jeffara tunisienne. Série usages, appropriation, gestion des écosystèmes, Documents de recherche du LPED, Université de Provence, France.

Rounsevell, M. D. A., and M. J. Metzger. 2010. Developing qualitative scenario storylines for environmental change assessment. Wiley Interdisciplinary Reviews: Climate Change 1 (4):606-619. http://dx.doi.org/10.1002/wcc.63

Scheffer, M., S. Carpenter, J. Foley, C. Folke, and B. Walker. 2001. Catastrophic shifts in ecosystems. Nature 413:591-596. http://dx. doi.org/10.1038/35098000

Schoemaker, P. J. H. 1993. Multiple scenario development: its conceptual and behavioral foundation. Strategic Management Journal 14(3):193-213. http://dx.doi.org/10.1002/smj.4250140304

Schoemaker, P. J. 1995. Scenario planning: a tool for strategic thinking. Sloan Management Review 36:25.

Schwartz, P. 1996. The art of the long view. Crown Publishing Group, New York, New York, USA.

Schweitzer, C., J. A. Priess, and S. Das. 2011. A generic framework for land-use modelling. Environmental Modelling \& Software 26 (8):1052-1055. http://dx.doi.org/10.1016/j.envsoft.2011.02.016

Sghaier, M., and D. Genin. 2003. La désertification dans la Jeffara Tunisienne: pratiques et usages des ressources, techniques de lutte et devenir des populations rurales. Institut des Régions Arides, Médenine, Tunisie.

Shamir, U., and J. T. Verhoeven, editors. 2013. Special issue on management of wetlands in river basins: the WETwin project. Environmental Science \& Policy 34:1-146 http://dx.doi. org/10.1016/j.envsci.2013.11.001

Shukla, J., R. Hagedorn, M. Miller, T. N. Palmer, B. Hoskins, J. Kinter, J. Marotzke, and J. Slingo. 2009. Strategies: revolution in climate prediction is both necessary and possible: a declaration at the World Modelling Summit for Climate Prediction. Bulletin of the American Meteorological Society 90(2):175-178. http://dx. doi.org/10.1175/2008BAMS2759.1

South African National Biodiversity Institute (SANBI). 2014. Grazing and burning guidelines: managing grasslands for biodiversity and livestock production. Compiled by R. G. Lechmere-Oertel. SANBI, Pretoria, South Africa. [online] URL: http://biodiversityadvisor.sanbi.org/wp-content/uploads/2014/07/ GrazingBurning-Guidelines.pdf

Statistics South Africa (SSA) 2011. Census 2011. Agricultural households: key highlights. SSA, Pretoria, South Africa. [online] URL: http://www.statssa.gov.za/census/census_2011/census_products/ Agricultural_Households.pdf

Steffen, W., K. Richardson, J. Rockström, S. E. Cornell, I. Fetzer, E. M. Bennett, R. Biggs, S. R. Carpenter, W. de Vries, C. A. de Wit, C. Folke, D. Gerten, J. Heinke, G. M. Mace, L. M. Persson, V. Ramanathan, B. Reyers, and S. Sörlin. 2015. Planetary boundaries: guiding human development on a changing planet. Science 347(6223). http://dx.doi.org/10.1126/science.1259855

Swart, R. J., P. Raskin, and J. Robinson. 2004. The problem of the future: sustainability science and scenario analysis. Global Environmental Change 14(2):137-146. http://dx.doi.org/10.1016/ j.gloenvcha.2003.10.002

Tversky, A., and D. Kahneman. 1974. Judgment under uncertainty: heuristics and biases. Science 185(4157):1124-1131. http://dx.doi.org/10.1126/science.185.4157.1124

U.N. Department of Economic and Social Affairs. 2013. World population prospects: the 2012 revision: Volume I: comprehensive tables. U.N. Department of Economic and Social Affairs, New York, New York, USA. [online] URL: https://esa.un.org/unpd/ wpp/Publications/Files/WPP2012_Volume-I_Comprehensive-Tables. pdf

U.N. Environment Programme (UNEP). 2006. Africa environment outlook 2: our environment, our wealth. UNEP, Nairobi, Kenya. [online] URL: http://wedocs.unep.org/ handle/20.500.11822/9626

van der Kamp, J., B. Fofana, and E. Wymenga. 2005. Ecological values of the Inner Niger Delta. Pages 154-177 in L. Zwarts, P. van Beukering, B. Krone, and E. Wymenga, editors. The Niger, a lifeline: effective water management in the Upper Niger Basin. RIZA, Lelystad / Wetlands International, Sévaré / Institute for Environmental studies (IVM), Amsterdam / A\&W ecological consultants, Veenwouden, Mali / The Netherlands.

van der Kwast, J., S. Yalew, C. Dickens, L. Quayle, J. Reinhardt, S. Liersch, M. Mul, M. Hamdard, and W. Douven. 2013. A framework for coupling land use and hydrological modelling for management of ecosystem services. International Journal of Environmental Monitoring and Analysis 1(5):230-236. http://dx. doi.org/10.11648/j.ijema.20130105.18

van Notten, P. W. F., J. Rotmans, M. B. A. van Asselt, and D. S. Rothman. 2003. An updated scenario typology. Futures 35 (5):423-443. http://dx.doi.org/10.1016/S0016-3287(02)00090-3

van Notten, P. W. F., A. Sleegers, and M. B. A. van Asselt. 2005. The future shocks: on discontinuity and scenario development. Technological Forecasting and Social Change 72(2):175-194. http://dx.doi.org/10.1016/j.techfore.2003.12.003

van Ruijven, B. J., M. A. Levy, A. Agrawal, F. Biermann, J. Birkmann, T. R. Carter, K. L. Ebi, M. Garschagen, B. Jones, R. Jones, E. Kemp-Benedict, M. Kok, K. Kok, M. C. Lemos, P. L. Lucas, B. Orlove, S. Pachauri, T. M. Parris, A. Patwardhan, A. Petersen, B. L. Preston, J. Ribot, D. S. Rothman, and V. J. Schweizer. 2014. Enhancing the relevance of shared 
socioeconomic pathways for climate change impacts, adaptation and vulnerability research. Climatic Change 122(3):481-494. http://dx.doi.org/10.1007/s10584-013-0931-0

van Vuuren, D. P., M. T. J. Kok, B. Girod, P. L. Lucas, and B. de Vries. 2012. Scenarios in global environmental assessments: key characteristics and lessons for future use. Global Environmental Change 22(4):884-895. http://dx.doi.org/10.1016/j.gloenvcha.2012.06.001

van Vuuren, D. P., E. Kriegler, B. C. O'Neill, K. L. Ebi, K. Riahi, T. R. Carter, J. Edmonds, S. Hallegatte, T. Kram, R. Mathur, and H. Winkler. 2014. A new scenario framework for climate change research: scenario matrix architecture. Climatic Change 122 (3):373-386. http://dx.doi.org/10.1007/s10584-013-0906-1

Vetter, T., J. Reinhardt, M. Flörke, A. van Griensven, F. Hattermann, S. Huang, H. Koch, I. G. Pechlivanidis, S. Plötner, O. Seidou, B. Su, R. W. Vervoort, and V. Krysanova. 2016. Evaluation of sources of uncertainty in projected hydrological changes under climate change in 12 large-scale river basins. Climatic Change 141:419-433. http://dx.doi.org/10.1007/s10584-016-1794$\mathrm{y}$

Walter, A. I., S. Helgenberger, A. Wiek, and R. W. Scholz. 2007. Measuring societal effects of transdisciplinary research projects: design and application of an evaluation method. Evaluation and Program Planning 30(4):325-338. http://dx.doi.org/10.1016/j. evalprogplan.2007.08.002

Walz, R. 2000. Development of environmental indicator systems: experiences from Germany. Environmental Management 25 (6):613-623. http://dx.doi.org/10.1007/s002670010048

Walz, A., C. Lardelli, H. Behrendt, C. G.-R. Lundstöm, S. Kytzia, and P. Bebi. 2007. Participatory scenario analysis for integrated regional modelling. Landscape and Urban Planning 81:114-131. http://dx.doi.org/10.1016/j.landurbplan.2006.11.001

Wilkinson, A., and E. Eidinow. 2008. Evolving practices in environmental scenarios: a new scenario typology. Environmental Research Letters 3(4):45017. http://dx.doi.org/10.1088/1748-9326/3/4/045017

White, D. D., A. Wutich, K. L. Larson, P. Gober, T. Lant, and C. Senneville. 2010. Credibility, salience, and legitimacy of boundary objects: water managers' assessment of a simulation model in an immersive decision theater. Science and Public Policy 37 (3):219-232. http://dx.doi.org/10.3152/030234210X497726

Yalew, S., T. Pilz, C. Schweitzer, S. Liersch, J. van der Kwast, M. L. Mul, A. van Griensven, and P. van der Zaag. 2014. Dynamic feedback between land-use and hydrology for ecosystem services assessment. In D. P. Ames, N. W. T. Quinn, A. E. Rizzoli, editors. 7th International Congress on Environmental Modelling and Software. International Environmental Modelling and Software Society (iEMSs), San Diego, California, USA. ISBN: 978-88-9035-744-2

Yates, D., J. Sieber, D. Purkey, and A. Huber-Lee. 2005. WEAP21 A demand-, priority-, and preference-driven water planning model: Part 1: model characteristics. Water International 30 (4):487-500. http://dx.doi.org/10.1080/02508060508691893

Zsuffa, I., and J. Cools. 2011. Drivers-states-impacts-responses: DSIR analysis at the study sites. 7th Framework Programme,
European Commission, Brussels, Belgium. [online] URL: $\underline{\text { http:// }}$ www.wetwin.eu/downloads/D3-2.pdf

Zwarts, L., and M. Diallo. 2005. Fisheries in the Inner Niger Delta. Pages 89-107 in L. Zwarts, P. van Beukering, B. Krone, and E. Wymenga, editors. The Niger, a lifeline: effective water management in the Upper Niger Basin, RIZA, Lelystad / Wetlands International, Sévaré / Institute for Environmental studies (IVM), Amsterdam / A\&W ecological consultants, Veenwouden. Mali / The Netherlands.

Zwarts, L., and J.-L. Frerotte. 2012. Water crisis in the Inner Niger Delta (Mali): causes, consequences, solutions. A\&W-report 1832. Altenburg \& Wymenga ecologisch onderzoek, Feanwâlden, the Netherlands. [online] URL: http://www.altwym.nl/uploads/ file/490 1369389376.pdf

Zwarts, L., and B. Kone. 2005. Rice production in the Inner Niger Delta. Pages 137-153 in L. Zwarts, P. van Beukering, B. Krone, and E. Wymenga, editors. The Niger, a lifeline: effective water management in the Upper Niger Basin, RIZA, Lelystad / Wetlands International, Sévaré/Institute for Environmental studies (IVM), Amsterdam / A\&W ecological consultants,vVeenwouden. Mali / The Netherlands.

Zwarts, L., P. van Beukering, B. Krone, and E. Wymenga, editors. 2005. The Niger, a lifeline: effective water management in the Upper Niger Basin, RIZA, Lelystad / Wetlands International, Sévaré / Institute for Environmental studies (IVM), Amsterdam / A\&W ecological consultants, Veenwouden. Mali / The Netherlands. 
Appendix 1. Additional information on case study areas.

Table A1.1: Main characteristics of case study areas

\begin{tabular}{|c|c|c|c|c|}
\hline Case study area & $\begin{array}{l}\text { Oum Zessar } \\
\text { Watershed } \\
\text { (OZW, Tunisia) }\end{array}$ & $\begin{array}{l}\text { Rwenzori region } \\
\text { (RWR, Uganda) }\end{array}$ & $\begin{array}{l}\text { Inner Niger } \\
\text { Delta } \uparrow \text { (IND, } \\
\text { Mali) }\end{array}$ & $\begin{array}{l}\text { Upper Thukela } \\
\text { (UTH, South } \\
\text { Africa) }\end{array}$ \\
\hline $\begin{array}{l}\text { Population } \\
\text { [approx.] }\end{array}$ & $20000 \ddagger$ & $1400000 \S$ & 850000 & 715 000प \\
\hline $\begin{array}{l}\text { Case study area } \\
{\left[\mathrm{km}^{2}\right]}\end{array}$ & 350 & 14000 & 40000 & 13000 \\
\hline $\begin{array}{l}\text { Approx. } \\
\text { elevation range } \\
\text { [m.a.s.1.] \# }\end{array}$ & $0-700 \dagger \dagger$ & $900-$ over 4000 & $260-270$ & $500-$ over $3000 t t$ \\
\hline $\begin{array}{l}\text { First } \\
\text { administrative } \\
\text { unit of } \\
\text { country } \S\end{array}$ & Medenine & Western region & Ségou, Mopti & KwaZulu-Natal \\
\hline $\begin{array}{l}\text { Second } \\
\text { administrative } \\
\text { unit of } \\
\text { country } \S\end{array}$ & $\begin{array}{l}\text { Beni Khadeche, } \\
\text { Medenine Nord, } \\
\text { Sidi Makhlouf }\end{array}$ & $\begin{array}{l}\text { Kasese, } \\
\text { Kabarole, } \\
\text { Bundibugyo }\end{array}$ & $\begin{array}{l}\text { Macina, } \\
\text { Mopti, Youwarou, } \\
\text { Ténenkou }\end{array}$ & uThukela \\
\hline Watershed & $\begin{array}{l}\text { Oum Zessar } \\
\text { watershed }\end{array}$ & $\begin{array}{l}\text { Upper White Nile } \\
\text { basin }\end{array}$ & Upper Niger basin & $\begin{array}{l}\text { Upper Thukela } \\
\text { basin }\end{array}$ \\
\hline $\begin{array}{l}\text { Annual rainfall } \\
{[\mathrm{mm}] \text { in the }} \\
\text { basin }\end{array}$ & $|160-220|$ & 900-1600पII & 200-600\#\# & $550-2000 \dagger+\dagger$ \\
\hline $\begin{array}{l}\text { Average annual } \\
\text { temperature } \\
{\left[{ }^{\circ} \mathrm{C}\right]}\end{array}$ & $19-21+t+$ & $20-30 \S \S \S$ & $|28-30| \mid$ & 17पITI \\
\hline $\begin{array}{l}\text { Main land } \\
\text { cover [\%] }\end{array}$ & $\begin{array}{l}\text { Natural shrubs } \\
(46) \\
\text { Agricultural } \\
\text { areas (42) }+t+\end{array}$ & $\begin{array}{l}\text { Agricultural areas } \\
(40) \\
\text { Grasslands (22) } \\
\text { Tropical high forest } \\
\text { not depleted (11) } \\
\# \# \#\end{array}$ & $\begin{array}{l}\text { Different } \\
\text { grassland types } \\
\text { Open water } \dagger \dagger \dagger \dagger\end{array}$ & $\begin{array}{l}\text { Grassland (55) } \\
\text { Bush land (18) } \\
++t+\end{array}$ \\
\hline Main land use & $\begin{array}{l}48.6 \% \\
\text { Arboriculture } \\
\text { (mainly olives), } \\
\text { Livestock } \\
\text { farming }\end{array}$ & $\begin{array}{l}\text { Smallholder } \\
\text { farming } \\
\text { Cash crops: coffee, } \\
\text { tea, cotton }\end{array}$ & $\begin{array}{l}\text { Livestock farming } \\
\text { Fishing } \\
\text { Farming (rice, } \\
\text { bourgou, } \\
\text { vegetables)|||| }\end{array}$ & $\begin{array}{l}\text { Subsistence } \\
\text { agriculture (0.5 to } 3 \\
\text { ha) }(5.6 \%) ; \\
\text { Commercial }(200- \\
2000 \text { ha, } 7.5 \%)\end{array}$ \\
\hline
\end{tabular}




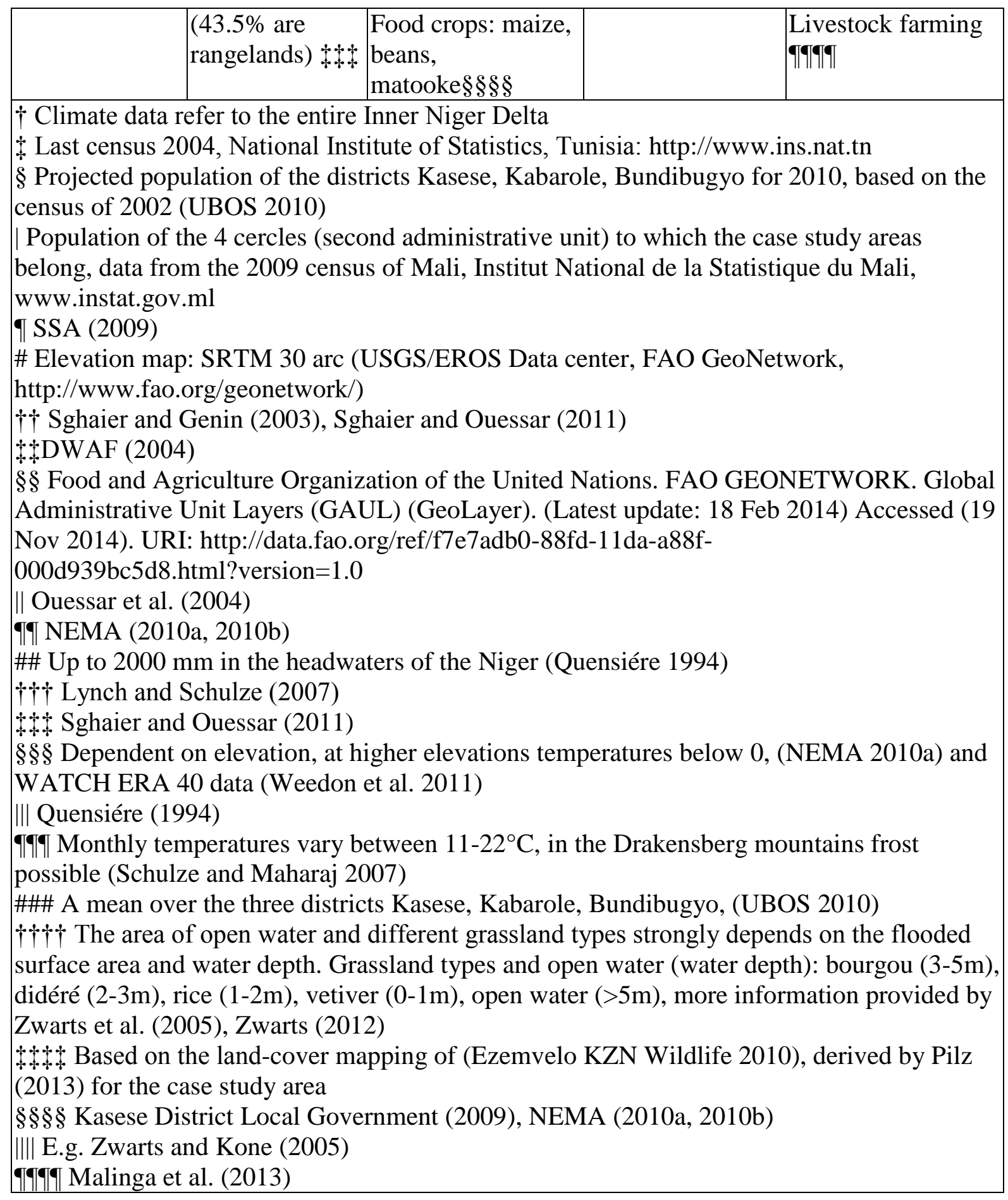


Box A1.1: Description of climate input data used in scenario assessments

For the reference periods in three of the case studies (OZW, IND, UTH) WATCH ERA40 forcing data were used (Weedon et al. 2011).

Inner Niger Delta, Mali (IND)

Climate change impacts were addressed using climate change projections of four Earth System Models (HadGEM2-ES, IPSL-CM5A-LR, GFDL-ESM2M, NorESM1-M) of the CMIP5 (Taylor et al. 2012) which were bias-corrected within the ISI-MIP project (Hempel et al. 2013). A low-end and high-end emission pathway (RCP 2.6 and 8.5) were considered.

Oum Zessar Watershed, Tunisia (OZW) and uThukela, South Africa (UTH)

A low-end and high-end emission pathway (RCP 2.6 and 8.5) of the five Earth System Models HadGEM2-ES, IPSL-CM5A-LR, MIROC-ESM-CHEM, GFDL-ESM2M, and NorESM1-M of the CMIP5 (Taylor et al. 2012) were used for the reference and future period. They were bias-corrected within the ISI-MIP project (Hempel et al. 2013). 
Details about the workshops on scenario assessments in the case studies

Oum Zessar watershed, Tunisia

Table A1.2: Overview of the workshops undertaken in the Oum Zessar watershed organised by the Institut des Régions Arides, Observatoire du Sahara et du Sahel and Potsdam Institute for Climate Impact Research

\begin{tabular}{|c|c|c|c|c|}
\hline Workshop number & 1 & 2 & 3 & 4 \\
\hline Duration (in days) & 2.5 & 0.5 & 2.5 & 1 \\
\hline Workshop content & $\begin{array}{l}\text { Development } \\
\text { of concept } \\
\text { map } \\
\text { Driver } \\
\text { analysis } \\
\text { Scenario } \\
\text { logics }\end{array}$ & $\begin{array}{l}\text { Scenario } \\
\text { logics } \\
\text { Ranking }\end{array}$ & $\begin{array}{l}\text { Fleshing out } \\
\text { scenarios } \\
\text { Scenario } \\
\text { implications }\end{array}$ & $\begin{array}{l}\text { Disseminatio } \\
\mathrm{n} \text { of scenario } \\
\text { products }\end{array}$ \\
\hline Total number of participants & 17 & 17 & 18 & 17 \\
\hline $\begin{array}{l}\text { Epistemic communities } \\
\text { (research } \\
\text { institutes and offices) }\end{array}$ & 11 & 8 & 8 & 8 \\
\hline $\begin{array}{l}\text { Policy communities (national } \\
\text { and regional policy makers, } \\
\text { donors) }\end{array}$ & 5 & 9 & 6 & $\begin{array}{l}7 \text { ( } 2 \text { national } \\
\text { policy } \\
\text { makers })\end{array}$ \\
\hline $\begin{array}{l}\text { Networks (farmers } \\
\text { organizations, the private } \\
\text { sector) }\end{array}$ & 0 & 0 & 0 & 0 \\
\hline $\begin{array}{l}\text { Advocacy coalitions (e.g. } \\
\text { NGOs) }\end{array}$ & 1 & 0 & 4 & 2 \\
\hline
\end{tabular}


Rwenzori region, Uganda

Table A1.3: Overview of the workshops undertaken in the Rwenzori region organised by Mountains of the Moon University

\begin{tabular}{|c|c|c|c|c|}
\hline Workshop number & 1 & 2 & 3 & $\overline{44}$ \\
\hline Duration (in days) & 1 & 2 & 1 & 1 \\
\hline Workshop content & $\begin{array}{l}\text { Focal issue } \\
\text { Driving } \\
\text { forces }\end{array}$ & $\begin{array}{l}\text { Analysis of } \\
\text { driving } \\
\text { forces and } \\
\text { interactions }\end{array}$ & $\begin{array}{l}\text { Development } \\
\text { of concept } \\
\text { map }\end{array}$ & Storylines \\
\hline Total number of participants & 24 & 6 & 6 & 15 \\
\hline $\begin{array}{l}\text { Epistemic communities } \\
\text { (research institutes and } \\
\text { offices) }\end{array}$ & 2 & 6 & 6 & 10 \\
\hline $\begin{array}{l}\text { Policy communities } \\
\text { (national and regional policy } \\
\text { makers, donors) }\end{array}$ & 6 & 0 & 0 & 0 \\
\hline $\begin{array}{l}\text { Networks (farmers } \\
\text { organizations, the private } \\
\text { sector) }\end{array}$ & 4 & 0 & 0 & 1 \\
\hline $\begin{array}{l}\text { Advocacy coalitions (e.g. } \\
\text { NGOs) }\end{array}$ & 12 & 0 & 0 & 4 \\
\hline
\end{tabular}


Inner Niger Delta, Mali

Table A1.4: Overview of the workshop undertaken for the Inner Niger Delta organised by Wetlands International

\begin{tabular}{ll}
\hline \hline Workshop number & 1 \\
\hline $\begin{array}{l}\text { Duration (in days) } \\
\text { Workshop content }\end{array}$ & $\begin{array}{l}\text { Define and agree on irrigation scenarios (in ha for } \\
\text { each irrigation schemes), on dam combinations and } \\
\text { the efficiency settings for Office du Niger }\end{array}$ \\
$\begin{array}{l}\text { Total number of participants } \\
\begin{array}{l}\text { Epistemic communities (research } \\
\text { institutes and offices) }\end{array}\end{array}$ & 41 \\
& 4 national \\
$\begin{array}{l}\text { Policy communities (national and } \\
\text { regional policy makers, donors) }\end{array}$ & 8 regional \\
& 4 local \\
$\begin{array}{l}\text { Networks (farmers organizations, } \\
\text { the private sector) }\end{array}$ & 7 \\
& 4 \\
\hline
\end{tabular}


uThukela, South Africa

Table A1.5: Overview of the workshop undertaken for the uThukela region organised by the Institute of National Resources Association

\begin{tabular}{|c|c|}
\hline Workshop number & 1 \\
\hline Duration (in days) & 2 \\
\hline Workshop content & $\begin{array}{l}\text { To develop a common understanding of the status } \\
\text { quo and to develop an integrated vision and } \\
\text { objectives for INRM in the basin } \\
\text { Information on planned project and scenario } \\
\text { assessment } \\
\text { Participatory analysis of main regional drivers and } \\
\text { processes in the frame of INRM }\end{array}$ \\
\hline Total number of participants & 36 \\
\hline $\begin{array}{l}\text { Epistemic communities (research } \\
\text { institutes and offices) }\end{array}$ & 6 \\
\hline $\begin{array}{l}\text { Policy communities (national and } \\
\text { regional policy makers, donors) }\end{array}$ & 20 \\
\hline $\begin{array}{l}\text { Networks (farmers organizations, } \\
\text { the private sector) }\end{array}$ & 3 \\
\hline Advocacy coalitions (e.g. NGOs) & 7 \\
\hline
\end{tabular}




\section{LITERATURE CITED}

SSA 2009. Community Survey 2007: Basic results - Kwazulu-Natal. Statistics South Africa. Pretoria. South Africa. [online] URL: http://www.statssa.gov.za/publications/Report-03-0135/Report-03-01-352007.pdf

DWAF. 2004. Internal strategic perspective: Thukela water management area. Department of Water Affairs and Forestry. DWAF Report No. P WMA 07/000/00/0304, South Africa. [online] URL: https://www.dwaf.gov.za/Documents/Other/WMA/7/ThukelalSPNov04full.pdf

Ezemvelo KZN Wildlife. 2010. 2008 KZN Province land-cover mapping: data users report and Meta data, P. O. Box 13053, Cascades, Pietermaritzburg. [online] URL: http://bgis.sanbi.org/BGISdownloads/Documents/KZN/KZN_2008_Landcover_FinalReport.pdf

Hempel , S., K. Frieler, L. Warszawski, J. Schewe, F. Piontek. 2013. A trend-preserving bias correction - the ISI-MIP approach. Earth System Dynamics 4: 219-236

Lynch, S., and R. Schulze. 2007. Rainfall database in R. Schulze, editor. South African Atlas of Climatology and Agrohydrology, Pretoria, RSA.

Malinga, R., L. J. Gordon, R. Lindborg, and G. Jewitt. 2013. Using participatory scenario planning to identify ecosystem services in changing landscapes. Ecology and Society 18(4): 10. http://dx.doi.org/10.5751/ES-05494-180410.

NEMA. 2010a. Environmental Sensitivity Atlas for the Albertine Graben, National Environment Management Authority, Kampala. [online] URL: http://www.nemaug.org/atlas/Sensitivity_Atlas_2009_May.pdf

NEMA. 2010b. State of the Environment Report for Uganda 2010, National Environment Management Authority, Kampala. [online] URL: http://library.health.go.ug/publications/service-delivery-public-health/environment-andsanitation/state-environment-report

Ouessar, M., M. Sghaier, N. Mahdhi, F. d. G. J. Abdelli, H. Chaieb, H. Yahyaoui, and D. Gabriels. 2004. An integrated approach for impact assessment of water harvesting techniques in dry areas: the case of Oued Oum Zessar watershed (Tunisia). Environmental Monitoring and Assessment 99:127-140.

Pilz, T. 2013. Influence of climate change and management on water availability and erosion in a meso-scale catchment in South Africa. M.Sc. thesis, University of Potsdam, Potsdam.

Quensiére, J. 1994. Environnement deltaïque in J. Quensiére, editor. La pêche dans le Delta Central du Niger. Karthala, Paris.

Schulze, R., and M. Maharaj. 2007. Daily mean temperatures in R. Schulze, editor. South African Atlas of Climatology and Agrohydrology, Pretoria, RSA.

Sghaier M. (coord.), Genin D. (coord.). (2003). Programme sur la désertification dans la Jeffara tunisienne : pratiques et usages des ressources, techniques de lutte et devenir des populations rurales. Médenine (Tunisie) : IRA. $155 \mathrm{p}$.

Sghaier, M., and M. Ouessar. 2011. Oum Zessar watershed. [online] URL: http://www.noveltis.com/desurvey/interface/site_oum_zessar.php.

Taylor, K.E., R.J. Stouffer, G.A. Meehl. 2012. An overview of CMIP5 and the experiment design. Bulletin of the American Meteorological Society 93(4): 485-498 
UBOS. 2010. 2010 Statistical abstract, Uganda Bureau of Statistics, Kampala. [online] URL: http://www.ubos.org/onlinefiles/uploads/ubos/pdf\%20documents/abstracts/Statistical\%20Abstract \%202010.pdf

Weedon, G. P., S. Gomes, P. Viterbo, W. J. Shuttleworth, E. Blyth, H. Österle, and J. C. Adam. 2011. Creation of the WATCH forcing data and its use to assess global and regional reference crop evaporation over land during the twentieth century. Journal of Hydrometeorology 12(5):823-848.

Zwarts, L. 2012. The impact of a lower river flow on the inundation, vegetation and land use in the Inner Niger Delta. A\&W-rapport 1868, Feanwâlden. [online] URL: http://www.altwym.nl/uploads/file/489_1369388731.pdf

Zwarts, L., I. Grigorias, and J. Hanganu. 2005. Vegetation of the lower inundation zone of the Inner Delta. Pages 109-119 in L. Zwarts, P. van Beukering, B. Krone, and E. Wymenga, editors. The Niger, a lifeline: effective water management in the Upper Niger Basin, RIZA, Lelystad / Wetlands International, Sévaré / Institute for Environmental studies (IVM), Amsterdam / A\&W ecological consultants, Veenwouden. Mali / The Netherlands.

Zwarts, L., and B. Kone. 2005. Rice production in the Inner Niger Delta. Pages 137-153 in L. Zwarts, P. van Beukering, B. Krone, and E. Wymenga, editors. The Niger, a lifetime: effective water management in the Upper Niger Basin, Mali / the Netherlands. 
Appendix 2. Additional results on scenario assessments.

\section{Rwenzori Region, Uganda}

Box A2.1: Assumed driver interactions and implications of the first scenario developed for the RWR

The first scenario, the "Autocratic dangerous scenario", is driven by a very effective but autocratic government which becomes increasingly influenced over time by funds dependent on international donors. Environmental laws are strictly enforced and contraventions severely punished. However, poor planning and too little investment into the educational system negatively affect environmental awareness. People's resistance against restrictions to access natural resources hinders the implementation of strategies on INRM. Socio-economic development in the RWR is slow due to low education levels, and alternative income sources for improving food access are lacking. The restrictions on access to natural resources in Rwenzori's protected areas increase pressures on the surrounding land to feed the growing population. With poor land management practices, soil and water resources degrade. Although the government aims to increase agricultural productivity and therefore permits the conversion of specific areas into cropland, food security has not improved much. 
Oum Zessar, Tunisia

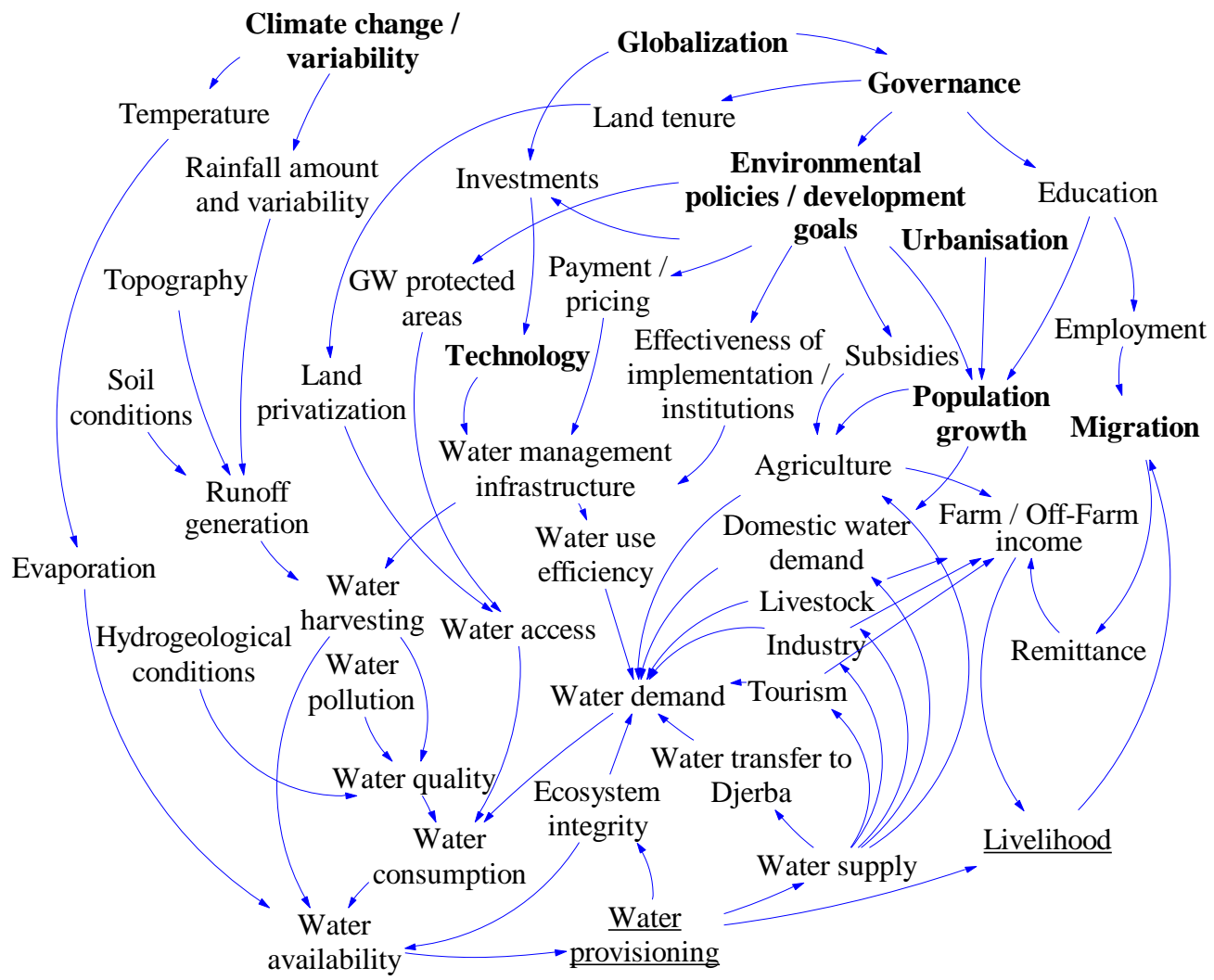

Figure A2.1: Concept map developed by the scenario team in Oum Zessar based on the focal issue: How to preserve and manage the water resources and the socio-agro-ecological system for sustainable development? The main drivers selected by the scenario team are in bold and the indicators for the impact assessment are underlined. 


\section{Details of the survey of local researchers to evaluate scenario processes and outcomes}

Table A2.1: Information on local researchers who participated in the survey, with the number of coauthors given in square brackets

\begin{tabular}{|c|c|c|c|}
\hline & $\begin{array}{l}\text { Number of } \\
\text { participants }\end{array}$ & $\begin{array}{l}\text { Key functions and responsibilities in the INRM } \\
\text { process }\end{array}$ & Professional background \\
\hline OZW & $4[1]$ & $\begin{array}{l}\text { Environmental scientists (Institut des Régions } \\
\text { Arides, Medenine, Tunisia) }\end{array}$ & $\begin{array}{l}\text { Economy (1), Hydrology (2), } \\
\text { Agro-Economy (1) }\end{array}$ \\
\hline RWR & $2[2]$ & $\begin{array}{l}\text { Environmental scientists (Mountains of the Moon } \\
\text { University, Fort Portal, Uganda) }\end{array}$ & $\begin{array}{l}\text { Agro-Ecology (1) } \\
\text { Natural resource management } \\
\text { and conservation (1) }\end{array}$ \\
\hline IND & $3[1]$ & $\begin{array}{l}\text { Environmental scientist (Wetlands International Mali } \\
\text { Office, Rural Development Officer) } \\
\text { Environmental scientist (NGO MCCAA in IND) } \\
\text { Regional Director of the Sustainable Development } \\
\text { Programme of IND }\end{array}$ & $\begin{array}{l}\text { Ecology and agriculture (1) } \\
\text { Ecology and zootechnics (1) } \\
\text { Engineer in water and forest } \\
\text { science (1) }\end{array}$ \\
\hline UTH & $2[1]$ & $\begin{array}{l}\text { Environmental scientists (International Water } \\
\text { Management Institute (IWMI), Pretoria, South } \\
\text { Africa and Institute of Natural Resources, } \\
\text { Pietermaritzburg, South Africa) }\end{array}$ & $\begin{array}{l}\text { Ecology (1, water resource } \\
\text { management), Environmental } \\
\text { management and resource } \\
\text { governance (1) }\end{array}$ \\
\hline
\end{tabular}


Table A2.2: Survey of local researchers on the usefulness of the scenario process and outcomes for sustainability research to feed into the INRM process in the case studies. The scores represent the overall evaluation of each group of researchers. They are on an ordinal scale from 1 to 5 with 1: I absolutely do not agree, 2: I do not agree, 3: I partially agree, 4: I agree, and 5: I fully agree.

\begin{tabular}{|c|c|c|c|c|c|}
\hline $\begin{array}{l}\text { Question } \\
\text { number }\end{array}$ & Survey question & OZW & RWR & IND & $\overline{\mathrm{UTH}}$ \\
\hline \multicolumn{6}{|c|}{ Credibility: the technical quality of the scenario process and outcomes } \\
\hline 1 & $\begin{array}{l}\text { There was sufficient knowledge and expertise of } \\
\text { participants involved in scenario building process }\end{array}$ & 5 & 4 & 4 & 5 \\
\hline 2 & $\begin{array}{l}\text { The scenario tool (approach, model) was adequate to } \\
\text { assess main system drivers }\end{array}$ & 4 & 4 & 4 & 5 \\
\hline 3 & $\begin{array}{l}\text { The scenario building approach was easy to } \\
\text { understand }\end{array}$ & 3 & 4 & 3 & 3 \\
\hline 4 & The developed scenarios are consistent and plausible & 3 & 4 & 5 & 4 \\
\hline 5 & $\begin{array}{l}\text { Adequate knowledge and facts were missing for } \\
\text { some important factors and relationships ( } 5 \text { for no, } 1 \\
\text { for many facts missing) }\end{array}$ & 4 & 5 & 4 & 4 \\
\hline \multicolumn{6}{|c|}{ Salience: the relevance of scenario process and outcomes } \\
\hline 1 & $\begin{array}{l}\text { The scenario outcomes are helpful in future activities } \\
\text { of your institute }\end{array}$ & 5 & 5 & 5 & 3 \\
\hline 2 & $\begin{array}{l}\text { The process and the scenarios improved the } \\
\text { understanding of future developments from different } \\
\text { perspectives }\end{array}$ & 5 & 5 & 5 & 4 \\
\hline 3 & $\begin{array}{l}\text { The scenario outcomes were documented in a way } \\
\text { which was understandable }\end{array}$ & 3 & 4 & 4 & 3 \\
\hline 4 & $\begin{array}{l}\text { The scenario outcomes were presented to decision- } \\
\text { makers (stakeholders) }\end{array}$ & 5 & 5 & 5 & 1 \\
\hline 5 & $\begin{array}{l}\text { The scenarios covered relevant themes and topics for } \\
\text { the actual INRM process }\end{array}$ & 4 & 5 & 4 & 5 \\
\hline 6 & $\begin{array}{l}\text { Scenario assessment contributed to the overall INRM } \\
\text { process in the region }\end{array}$ & 3 & 5 & 5 & 2 \\
\hline 7 & The scenario assessment met the defined targets & 3 & 5 & 4 & 1 \\
\hline 8 & $\begin{array}{l}\text { The topics treated in scenarios were, independently } \\
\text { of our research, also a matter of concern in local } \\
\text { media or the public }\end{array}$ & 5 & 5 & 5 & 5 \\
\hline 9 & $\begin{array}{l}\text { There have been parallel activities taking place on } \\
\text { INRM by administration / planning / legislation / } \\
\text { NGOs }\end{array}$ & 5 & 5 & 5 & 5 \\
\hline Legitimac & the fairness of the process & & & & \\
\hline
\end{tabular}




\begin{tabular}{|c|c|c|c|c|c|}
\hline 1 & $\begin{array}{l}\text { Improved process / dialogue between stakeholders } \\
\text { and scientists involved in INRM during the process }\end{array}$ & 4 & 5 & 4 & 5 \\
\hline 2 & $\begin{array}{l}\text { The targets of the scenario process were clear to all } \\
\text { participants }\end{array}$ & 4 & 3 & 5 & 4 \\
\hline 3 & $\begin{array}{l}\text { The targets of the scenario process were shared by all } \\
\text { participants }\end{array}$ & 4 & 5 & 5 & 3 \\
\hline 4 & $\begin{array}{l}\text { The scenario process took into account diverging } \\
\text { values and preferences of involved participants }\end{array}$ & 5 & 4 & 5 & 4 \\
\hline 5 & The process allowed for open participation & 2 & 5 & 5 & 2 \\
\hline \multicolumn{6}{|c|}{ Capacity building: usefulness for future activities of the research team } \\
\hline 1 & $\begin{array}{l}\text { The applied techniques, models or tools for scenario } \\
\text { assessments will be used in future research activities }\end{array}$ & 5 & 5 & 4 & 3 \\
\hline 2 & $\begin{array}{l}\text { The scenario process enhanced the understanding of } \\
\text { feedbacks between nature and human system }\end{array}$ & 5 & 5 & 4 & 4 \\
\hline 3 & $\begin{array}{l}\text { The scenario process enhanced understanding of } \\
\text { main urgent sustainability problems }\end{array}$ & 5 & 5 & 5 & 4 \\
\hline 4 & $\begin{array}{l}\text { The scenario process enhanced knowledge about } \\
\text { thresholds of the system of analysis }\end{array}$ & 3 & 4 & 5 & 4 \\
\hline 5 & $\begin{array}{l}\text { The scenario process enhanced knowledge about key } \\
\text { uncertainties }\end{array}$ & 5 & 5 & 4 & 4 \\
\hline 6 & $\begin{array}{l}\text { The scenario process enhanced knowledge about } \\
\text { spatial scale-interactions \& scale dependencies }\end{array}$ & 3 & 5 & 5 & 4 \\
\hline 7 & $\begin{array}{l}\text { The scenario process enhanced knowledge about } \\
\text { bringing together long term sustainability goals and } \\
\text { short term decision making }\end{array}$ & 2 & 5 & 5 & 4 \\
\hline 8 & $\begin{array}{l}\text { The scenario process enhanced knowledge about } \\
\text { implications of human behavior for sustainability } \\
\text { goals }\end{array}$ & 3 & 5 & 5 & 4 \\
\hline 9 & $\begin{array}{l}\text { The scenario process enhanced knowledge about } \\
\text { people's values and preferences for future } \\
\text { development }\end{array}$ & 3 & 5 & 5 & 2 \\
\hline 10 & $\begin{array}{l}\text { The scenario process enhanced knowledge about } \\
\text { potential sustainable transition pathways }\end{array}$ & 5 & 4 & 3 & 4 \\
\hline 11 & $\begin{array}{l}\text { The scenario process contributed to the process of } \\
\text { prioritizing management options }\end{array}$ & 4 & 4 & 5 & 2 \\
\hline 12 & $\begin{array}{l}\text { The scenario process contributed to the process of } \\
\text { assessing the impact of management options }\end{array}$ & 2 & 4 & 5 & 2 \\
\hline 13 & $\begin{array}{l}\text { The scenario process contributed to the process of } \\
\text { implementing management options }\end{array}$ & 2 & 5 & 3 & 1 \\
\hline 14 & $\begin{array}{l}\text { The scenario process improved the knowledge to deal } \\
\text { with surprising events / abrupt changes }\end{array}$ & 5 & 5 & 2 & 3 \\
\hline
\end{tabular}


Appendix 3. Additional information on methods.

Box A3.1: Author's contribution to this study

- Definition of indicators, preparation of survey (JR, in consultation with SL)

- Scenario assessments

○ OZW (JR, SL, MA, MLM)

○ RWR (JR, SL, CK, MM)

- IND (SL, MD, SF)

○ $\operatorname{UTH}(\mathrm{JR}, \mathrm{SL}, \mathrm{CD}, \mathrm{TP})$

- Analysis of implementation of indicators in case studies (JR, SL)

- Survey on scenario assessments (MA, MD, CD, CK, MM)

- Overall evaluation of the usefulness of scenario assessments (JR, in consultation with SL)

- Critical review of manuscript (all)

Table A3.1: Operationalization of the nine research challenges identified by Swart et al. (2004) with survey questions related to the four criteria of research efficiency.

\begin{tabular}{|l|l|}
\hline $\begin{array}{l}\text { Research challenges of sustainability science } \\
\text { (Swart et al. 2004) }\end{array}$ & $\begin{array}{l}\text { Criteria of research efficiency (and survey } \\
\text { questions) that link to the research challenges } \\
\text { (the survey can be found in Tab. A2.2) }\end{array}$ \\
\hline $\begin{array}{l}\text { 1. Combining qualitative and quantitative } \\
\text { analysis }\end{array}$ & Credibility (q. 1 to 5) \\
\hline 2. Engaging stakeholder & Legitimacy (q.1 to 5), Salience (q. 4) \\
\hline $\begin{array}{l}\text { 3. Reflecting multiple stresses and functional } \\
\text { complexity }\end{array}$ & Capacity building (q. 2,3,5) \\
\hline 4. Integrating across themes and issues & Capacity building (q. 2, 3) \\
\hline 5. Accounting for volition & Capacity building (q. 8, 11-13) \\
\hline 6. Recognising a wide range of outlooks & Capacity building (q. 9, 10) \\
\hline 7. Spanning spatial scales & Capacity building (q. 6) \\
\hline 8. Accounting for temporal inertia and urgency & Capacity building (q. 7) \\
\hline $\begin{array}{l}\text { 9. Reflecting uncertainty, incorporating } \\
\text { surprise, critical thresholds, and abrupt change }\end{array}$ & $\begin{array}{l}\text { Capacity building } \\
\text { (q. 4, 5, 14) }\end{array}$ \\
\hline
\end{tabular}

